\title{
Physiological and therapeutic regulation of PCSK9 activity in cardiovascular disease
}

\author{
Simon Glerup ${ }^{1} \cdot$ Rainer Schulz $^{2} \cdot$ Ulrich Laufs $^{3} \cdot$ Klaus-Dieter Schlüter $^{2}$ (I)
}

Received: 18 January 2017/ Accepted: 7 April 2017/Published online: 24 April 2017

(c) The Author(s) 2017. This article is an open access publication

\begin{abstract}
Ischemic heart disease is the main cause of death worldwide and is accelerated by increased levels of lowdensity lipoprotein cholesterol (LDL-C). Proprotein convertase subtilisin/kexin type 9 (PCSK9) is a potent circulating regulator of LDL-C through its ability to induce degradation of the LDL receptor (LDLR) in the lysosome of hepatocytes. Only in the last few years, a number of breakthroughs in the understanding of PCSK9 biology have been reported illustrating how PCSK9 activity is tightly regulated at several levels by factors influencing its transcription, secretion, or by extracellular inactivation and clearance. Two humanized antibodies directed against the LDLR-binding site in PCSK9 received approval by the European and US authorities and additional PCSK9 directed therapeutics are climbing up the phases of clinical trials. The first outcome data of the PCSK9 inhibitor evolocumab reported a significant reduction in the composite endpoint (cardiovascular death, myocardial infarction, or stroke) and further outcome data are awaited. Meanwhile, it became evident that PCSK9 has (patho)physiological roles in several cardiovascular cells. In this review, we summarize and discuss the recent biological and clinical data on PCSK9, the regulation of PCSK9, its extra-hepatic activities focusing on cardiovascular cells, molecular
\end{abstract}

Klaus-Dieter Schlüter

Klaus-Dieter.Schlueter@physiologie.med.uni-giessen.de

1 Department of Biomedicine, Aarhus University, 8000 Aarhus C, Denmark

2 Department of Physiology, Justus-Liebig-University, Aulweg 129, 35392 Giessen, Germany

3 Universitätsklinikum des Saarlandes, 66421 Homburg/Saar, Germany concepts to target PCSK9, and finally briefly summarize the data of recent clinical studies.

Keywords LDL · oxLDL · LDL receptor

\section{Introduction}

Proprotein convertase subtilisin/kexin type 9 (PCSK9) regulates the low-density lipoprotein (LDL) receptor (LDLR) by a mechanism that appears to be rather unique in biology. However, despite the high current interest, important details remain to be understood about how PCSK9 mediates LDLR degradation.

\section{PCSK9 shifts LDLR traffic from recycling to degradation in hepatic cells}

Proprotein convertase subtilisin/kexin type 9 is a member of the proprotein convertase superfamily of serine proteinases also encompassing proprotein convertases $1,2,4$, 5,7 , furin, paired basic amino-acid cleaving enzyme 4, and subtilisin kexin isozyme-1 [176]. The only PCSK9 substrate identified so far is its own prodomain: ProPCSK9 undergoes autocleavage at position $\operatorname{Gln}^{152}$ and this is a prerequisite for subsequent passage through the secretory pathway [12]. Interestingly, the cleaved prodomain remains firmly attached by strong hydrophobic interactions in the putative substrate-binding cavity of the catalytic domain, thereby preventing PCSK9 from interacting with other substrates. Instead, PCSK9 binds to the extracellular domains of a highly selective subset of transmembrane receptors including LDLR and targets them for degradation in lysosomes by a mechanism that apparently is independent of PCSK9 proteolytic activity [170, 173]. The LDLR 
binds LDL cholesterol (LDL-C) and removes it from the circulation by endocytosis via clathrin coated pits. The acidic $\mathrm{pH}$ of endosomes causes LDLR to dissociate from LDL-C. LDLR recycles to the cell surface, while the LDL$\mathrm{C}$ particle is degraded in lysosomes and the recovered cholesterol is used by the cell. LDLR bound to PCSK9 is also endocytosed by a clathrin-dependent mechanism, but the strength of the binding is increased at acidic $\mathrm{pH}$, and instead of recycling, the entire complex is destined for lysosomal degradation [141, 203, 204]. Accordingly, overexpression of PCSK9 in experiments in mice, hamsters, and pigs results in reduced number of LDLR accompanied by marked increases in plasma LDL-C $[5,16,118,120,141]$. In contrast, PCSK9 knockout mice are characterized by increased LDLR expression and reduced LDL-C [148]. Similarly, genome editing, using a clustered regularly interspaced short palindromic repeats (CRISPR)/CRISPR-associated system, effectively downregulates hepatic expression of PCSK9 with the subsequent expected up-regulation of LDLR and reduction in plasma LDL-C in mice [41].

\section{From genetics to function}

A few months after the initial publication on PCSK9 by Seidah and colleagues [174], the first report on gain-offunction (GOF) mutations in PCSK9 causing autosomal dominant hypercholesterolemia was published [1]. This initial finding rapidly prompted several other genetic studies linking PCSK9 mutations with familial hypercholesterolemia $[103,180,192]$ and the pivotal discovery in 2004 that PCSK9 overexpression in the liver resembles an LDLR knockout phenotype [120]. In 2005, loss-offunction (LOF) PCSK9 mutations including two nonsense mutations (Y142X and C679X) were discovered, conferring reduced LDL-C [31] and protecting against coronary artery disease [30]. PCSK9 GOF mutations with known functional consequences include the S127R and D374Y variants which display several folds increased affinity for LDLR [35]. Other PCSK9 GOF variants are R218S and F216L, and these are resistant to furin-mediated proteolytic inactivation as discussed below [13]. Furthermore, although the mechanism is currently unclear, a number of known GOF variants are associated with increased passage of PCSK9 through the biosynthetic pathway. Conversely, a number of LOF variants display reduced processing and exit from the endoplasmic reticulum as a consequence of compromised folding and stability $[11,133]$. Studies of GOF and LOF PCSK9 mutations provided valuable insights into the biological activity of PCSK9 and lay the foundation for the development of therapeutic PCSK9 inhibitors.

\section{Contributions of $\mathrm{N}$ - and $\mathrm{C}$-terminal domains to PCSK9 activity}

PCSK9 consists of three domains: the N-terminal prodomain followed by the catalytic domain and the $\mathrm{C}$-terminal domain. The catalytic domain mediates the direct interaction with the epidermal growth factor (EGF) A domain of the LDLR as demonstrated by various biochemical methods including crystallography [35, 94, 115]. However, elements of the PCSK9 prodomain appear to have a modulatory effect on LDLR degradation activity as deletion of the amino-acid sequence stretch $31-58$ in the prodomain results in a PCSK9 variant with four to sevenfold increased LDLR degrading activity. The prodomain sequence is rich in acidic residues and has been suggested to play an autoinhibitory role through interaction with the basic residues in the PCSK9 catalytic domain [14]. Another possible regulatory function of the acid prodomain sequence has been proposed as around $40 \%$ of PCSK9 in plasma is associated with LDL-C particles and in vitro prodomain truncation variant lacking residues $31-52$ is unable to bind LDL-C [207]. Furthermore, in cell-based experiments LDL-C particles lower the LDLR degradation activity of PCSK9 [91]. Thus, high LDL-C may provide a feedback mechanism to decrease PCSK9 activity. This effect is clearly not decisive as evident from the potent effect of PCSK9 inhibitors in lowering LDL-C in clinical trials (see section "Studies of PCSK9-inhibition in patients with high cardiovascular risk").

The C-terminal domain of PCSK9 is required for its ability to induce LDLR degradation as a truncated PCSK9 variant lacking the $\mathrm{C}$-terminal domain display reduced activity against LDLR, whereas the isolated C-terminal domain alone has no effect on LDLR degradation [210]. The role of the PCSK9 C-terminal domain is strongly supported by data using a monoclonal antibody directed against the C-terminal domain which inhibits the ability of PCSK9 to reduce LDL-C uptake in cells and decreases plasma LDL-C in cynomolgus monkeys [134, 165]. Notably, amyloid precursor-like protein 2 (APLP2) acts as a PCSK9 receptor as demonstrated by affinity purification from $\mathrm{HepG} 2$ cells followed by mass spectrometry. APLP2 binds to the PCSK9 C-terminal domain with an increasing amount of complex formed at decreasing $\mathrm{pH}$. APLP2 mediates PCSK9 endocytosis alone or in complex with LDLR, and is critically involved in the lysosomal targeting of PCSK9 and the PCSK9:LDLR complex [39, 40]. Similarly, annexin-2 binds to the C-terminal domain of PCSK9 and functions as an endogenous inhibitor of its activity [120]. Accordingly, mice lacking annexin 2 displayed increased plasma PCSK9 and LDL-C and reduced LDLR, while overexpression of annexin 2 increased liver LDLR [176]. 


\section{The PCSK9 receptor $X$}

Since the discovery of PCSK9-induced LDLR degradation, it has been a puzzle how a soluble monomeric protein like PCSK9 can have a dramatic effect on the intracellular trafficking of a transmembrane type 1 receptor such as LDLR. Furthermore, the LDLR C-terminus is not absolutely required for PCSK9-induced degradation. LDLRtransferrin receptor chimera with the LDLR C-terminal substituted for that of the transferrin receptor domain as well as a truncated LDLR variant lacking the C-terminus are still degraded albeit at slower rates [78, 186]. The average PCSK9 plasma concentration is around $6 \mathrm{nmol} / \mathrm{L}$, but the affinity constant $\left(K_{\mathrm{d}}\right)$ for the PCSK9:LDLR interaction at a $\mathrm{pH}$ corresponding to that of plasma has been measured using Biacore to be around 170 and $628 \mathrm{nmol} / \mathrm{L}$, respectively [35, 53, 95]. Interestingly, the same studies found that at lower $\mathrm{pH}$, the affinity was markedly increased and the reported $K_{\mathrm{d}}$ values were $62 \mathrm{nmol} / \mathrm{L}$ (pH 5.4) [35] and $4.2 \mathrm{nmol} / \mathrm{L}(\mathrm{pH}$ 5.3) [53]. Taken together, these observations suggest the existence of additional high affinity PCSK9 receptors that take part in the LDLR degradation complex.

\section{Molecular pathways regulating PCSK9 expression}

Proprotein convertase subtilisin/kexin type 9 expression is highly restricted both developmentally and in tissues [174]. In adult mice, the highest PCSK9 mRNA levels by far are found in the liver and substantially lower expression is also found in the brain, kidney, and small intestine [191]. Thus, circulating PCSK9 appears to be produced mainly by the liver and its expression is regulated by numerous factors such as diurnal rhythm, hormones (including estrogen, insulin, resistin, and thyroid hormone), diet, exercise, and various cholesterol lowering drugs.

\section{Regulation of PCSK9 expression by statins}

Soon after the discovery of PCSK9, it was reported that statins up-regulate PCSK9 gene expression in HepG2 cells and primary hepatocytes [48]. PCSK9-deficient mice are hypersensitive to statin treatment compared to wild-type mice [148]. These observations from cells and animals have translated into humans: a first report of patients receiving atorvastatin showed a $34 \%$ increase in circulating PCSK9 levels in response to treatment [25] and a recent meta-analysis including 15 clinical trials examining the effect of statins on plasma PCSK9 levels showed that statins significantly increase plasma PCSK9 irrespective of the type of statin [164]. Interestingly, several additional lipid-lowering drugs including fenofibrates increase
PCSK9 expression and thereby counteract their own pharmacological activity [163, 195].

\section{Regulatory elements in the PCSK9 promoter}

Up-regulation of PCSK9 by cholesterol depletion or inhibition of intracellular cholesterol synthesis by, e.g., statins is explained by a sterol-regulatory element (SRE) [48], which have found to be regulated by sterol-regulatory elementbinding protein-2 (SREBP-2) and SREBP-1c [32, 81, 157]. In close vicinity to the SRE, the PCSK9 gene contains a highly conserved hepatocyte nuclear factor 1 (HNF1)binding site and HNF1 $\alpha$ cooperates with SREBP-2 to regulate PCSK9 expression in HepG2 cells [107] and in the liver [45, 179]. Furthermore, liver-specific knockdown of HNF1 antagonizes statin-induced induction of PCSK9 transcription [44]. In analogy, mice with liver-specific knockout of SREBP-2 display a marked reduction in PCSK9 expression. A binding site for histone nuclear factor $\mathrm{P}$ (HINFP) is located between the SRE and HNF1 site in the PCSK9 promotor. HINFP was suggested as a positive regulator of PCSK9 transcription through facilitation of histone H4 acetylation at the PCSK9 promoter through a complex of HINFP, its cofactor nuclear protein of the ATM locus (NPAT), and the histone acetyltransferase cofactor transformation/transcription domain-associated protein (TRRAP) [108]. Along this line, deficiency of the histone deacetylase Sirtuin 6 (Sirt6) in the liver leads to elevated PCSK9 expression. As underlying mechanism recruitment of Sirt6 to the PCSK9 promoter by the transcription factor forkheadbox protein $\mathrm{O} 3$ (FoxO3), leading to deacetylation of histone H3, thereby repressing PCSK9 transcription by suppressing HNF1 activity [190]. Furthermore, Sirt6 and FoxO3 also suppress hepatic SREBP-2 transcription [189]. Interestingly, Sirt6 and FoxO3 are active during fasting but decrease upon feeding, and both genes are associated with longevity, possibly through their effect on LDL-C clearance [190]. In accordance with these findings, PCSK9 expression decreases by fasting by a mechanism that is apparently insulin-independent $[32,125]$. Furthermore, the pharmacological activation of the related deacetylase Sirt1 leads to a marked reduction in PCSK9 secretion through an unknown posttranslational mechanism [126]. Figure 1 summarizes some aspects of regulatory elements of the PCSK9 promoter mentioned here.

\section{Insulin signaling, diabetes, and PCSK9 expression}

Constitutive expression of PCSK9 and LDLR has been demonstrated in pancreatic islet $\beta$ cells [122]. Here, depletion of PCSK9 also increases LDLR, but it is also associated with low insulin expression. Pancreatic islet $\beta$-cells in PCSK9 null mice show all signs of inflammation, apoptosis, 


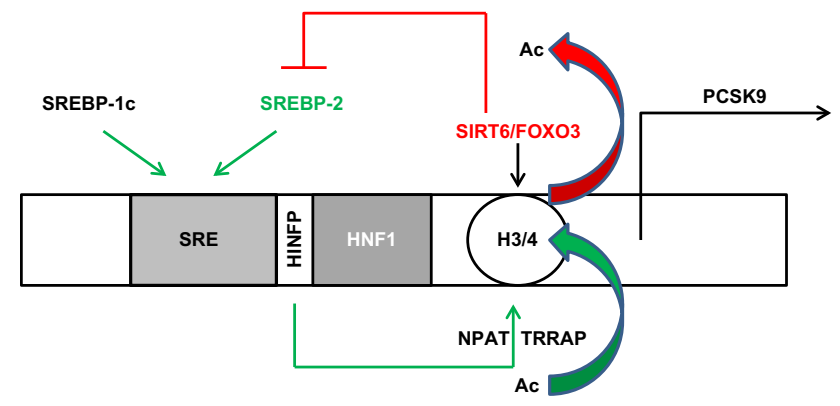

Fig. 1 Regulation of PCSK9 promoter region in hepatic cells. Pathways that increase the expression are indicated in green and those that depress expression of PCSK9 are indicated in red. The sterol-regulatory element (SRE) is activated by SREBP1c and SREBP2 that coactive hepatocyte nuclear factor (HNF)-1. The histone $\mathrm{H} 3$ is deacetylated by SIRT6/FOXO3 complexes and histone H4 is acetylated by HINPF/NPAT/TRRAP complexes

and malformation. PCSK9 expression is associated with insulin signaling, possibly through an effect of insulin on SREBP-1c [32]. Insulin is reported to increase PCSK9 expression in hepatoma cells and primary hepatocytes $[32,125]$, while another study found that insulin decreases PCSK9 expression and secretion from human cell lines [8]. In humans, plasma PCSK9 concentrations are positively associated with insulin concentration [93] and insulin resistance [75, 104]. PCSK9 expression is markedly reduced in mice lacking the insulin receptor in the liver with pharmacologically induced insulin deficiency. However, insulin receptor knockdown in the liver was only effective in reducing PCSK9 expression in obese mice but not in lean wild-type mice [125]. Instead, in a different study, insulin repressed hepatic PCSK9 expression via activation of insulin receptors and subsequent activation of protein kinases finally leading to protein kinase $\mathrm{C}$ (PKC) $\delta$-dependent inhibition of HNF4 $\alpha$ and HNF1 $\alpha$ [3]. Indeed, hepatic expression of PCSK9 is reduced under diabetic conditions, whereas hepatic LDLR expression remains high, but obviously functional inactive [136]. In vivo studies showed that hyperinsulinemic euglycemic clamp resulted in a marked increase in PCSK9 expression in mice [32], whereas a moderately hyperinsulinemic glucose clamp for $24 \mathrm{~h}$ had no effect on PCSK9 plasma concentrations in healthy and type 2 diabetic men [84]. In a different study, PCSK9 plasma levels dropped acutely following hyperinsulinemic euglycemic clamp in obese postmenopausal women confirming the mouse data [125], suggesting that PCSK9 levels are dynamically regulated following an insulin or glucose challenge [8]. Importantly, there is evidence for sex-specific regulation of PCSK9 in young adults [105]. Thus, it seems that the outcome of insulin signaling on PCSK9 expression is highly sensitive to the experimental setup and the exact metabolic state of the animals or human subjects used for testing. High fructose diet increases circulating PCSK9 both in healthy human subjects [26] and in animals with concomitant effect on LDLR protein levels [43]. Having summarized these experimental data, it has to be mention that PCSK9 variants associated with lower LDL-C displayed an increased type-2-diabetes risk [167]. Furthermore, in type-1diabetes, good glycaemic control abolishes the relationship between PCSK9 and LDL-C [101] indicating a complex and yet not fully interaction between glucose-, LDL-C, and PCSK9 regulation. Nevertheless, there is no evidence yet for new onset of diabetes in patients under PSCK9 inhibition [6].

\section{Circadian regulation of PCSK9 expression}

Changes in plasma PCSK9 levels are synchronous with cholesterol synthesis under noninterventional conditions. Interestingly, disruption of the circadian rhythmicity of liver gene expression in liver-specific aryl hydrocarbon receptor nuclear translocator-like protein 1 (=Bmal1) knockout mice results in marked increases in PCSK9 levels and concomitantly reduced LDLR with subsequent increase of LDL-C [117]. Bmal1 targets the transcriptional regulation of hundreds of genes including all of the clock genes and a number of genes encoding metabolic regulators. Loss of Bmal1 markedly reduces expression of the Tribbles homolog 1, a protein involved in the turnover of transcription factor CCAAT/enhancer-binding protein $\alpha$ $(\mathrm{C} / \mathrm{EBP} \alpha)$ and also in the phosphorylation and activation of mitogen activated protein (MAP) kinase both resulting in the inhibition of lipogenic gene transcription [10], including PCSK9 [117]. Interestingly, variants near the TRIB1 gene locus have repeatedly been genome-wide significantly associated with all plasma lipid traits [64]. Peroxisome proliferator-activated receptor $\gamma(\operatorname{PPAR} \gamma)$ activation induces PCSK9 transcription. MAP kinase activation decreases PCSK9 expression, which is possibly through PPAR $\gamma$ dephosphorylation. Accordingly, PCSK9 expression in HepG2 cells is induced by MAP kinase inhibition [47]. The effect of PPAR $\gamma$ activity on PCSK9 transcription is associated with increased processing of SREBP-2 [47]. The effects of insulin and PPAR $\gamma$ on the regulation of PCSK9 expression are summarized in Fig. 2.

\section{Cross talk between cytokine signaling and PCSK9 expression}

Interestingly, cytokines such as tumor necrosis factor (TNF) $\alpha$ or activation of the Janus kinase/signal transducer and activator of transcription (JAK/STAT) pathway has notable effect on PCSK9 expression in HepG2 cells and in vivo. As such, pharmacological activation of this pathway suppresses PCSK9 transcription [24]. On the other hand, suppressor of cytokine signaling SOCS3, which is a 


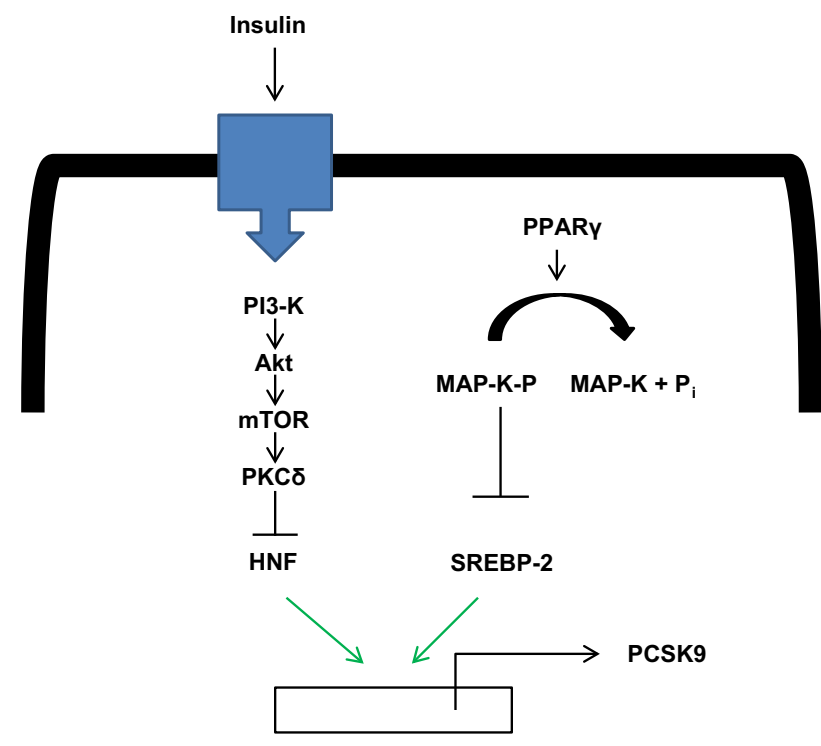

Fig. 2 Effect of insulin and PPAR $\gamma$ on PCSK9 expression. Insulin activates a classical insulin receptor signaling cascade leading to a depression of HNF1 and thereby PCSK9 expression. PPAR $\gamma$ activates PCSK9 transcription by attenuating MAP-kinase-dependent brake on PCSK9 expression

negative regulator of JAK/STAT, induces PCSK9 expression through activation of SREBP-1 [159]. Furthermore, the inflammatory cytokine resistin induces PCSK9 expression in human hepatocytes [124]. Intriguingly, the PCSK9 C-terminal domain displays structural resemblance to resistin suggesting both a structural and functional relationship between cytokine signaling and PCSK9 [73]. These observations are interesting considering that PCSK9 recently was described as a critical regulator of the innate immune response and survival following sepsis in both mice and humans [200].

In conclusion, several factors regulate PCSK9 expression, but it remains to be understood what controls the tissue specificity and the developmentally restricted PCSK9 expression.

\section{Posttranslational regulation of PCSK9 activity}

Recently, it has become clear that PCSK9 activity is tightly regulated at the posttranslational level by a number of factors that regulates its secretion, extracellular inhibition or inactivation, and its clearance from the circulation.

\section{PCSK9 regulatory check points in the secretory pathway}

In addition to the extracellular pathways, PCSK9 may also function intracellularly by sequestering LDLR in its biosynthetic pathway as PCSK9 and LDLR are both synthesized by hepatocytes. Of note many of the naturally occurring LOF mutations in PCSK9 result in altered proPCSK9 processing or reduced secretion from the cell, whereas mutations associated with hypercholesterolemia resulted in increased cellular exit of PCSK9 [133]. The mechanism for this remains unknown but suggests that the passage of PCSK9 through the biosynthetic pathway is tightly controlled. Understanding of the pathway may be of clinical importance to assess potential differential effects of extracellular PCSK9 inhibitors such as antibodies and inhibitors with intracellular effects.

\section{PCSK9 in the endoplasmic reticulum}

The chaperone heat-shock protein $90 \mathrm{kDa} \beta$ member 1 (=GRP94) residing in the endoplasmic reticulum (ER) binds PCSK9 and prevents its ability to sequester LDLR prematurely in the ER [145]. Mice lacking GRP94 have increased plasma LDL-C and a highly reduced LDLR level in the liver. Proteins destined for secretion can either exit the ER by the so-called bulk flow pathway or they can be guided by specific ER-residing sorting receptors [36]. The ER sorting receptor for PCSK9 is the coat protein complex II (COPII) vesicle adaptor protein SEC24A, since it is required for efficient exit of PCSK9 from the ER [29]. SEC24A is highly enriched in the liver and SEC24A knockout mice display reduced plasma PCSK9 and LDL-C but increased liver LDLR. COPII vesicles cycle between ER and the cis-Golgi and receptors are known to direct specific cargo into these vesicles, thereby increasing the speed of their ER exit. This traffic is again guided by specific adaptor proteins such as SEC24A. However, in the case of PCSK9 and SEC24A, the receptor remains to be identified. Endoplasmatic stress on the other hand reduces PCSK9 secretion [102].

\section{Sorting of PCSK9 by sortilin}

Sortilin 1 (SORT1) encoding the transmembrane type I receptor sortilin is a risk gene for hypercholesterolemia and myocardial infarction [7, 87, 90]. Sortilin is highly expressed in a number of tissues in a distinct and dynamic fashion [17]. It is involved in cellular processes including cell death and survival as well as regulation of neurotrophic activity in the peripheral and central nervous system [66]. Sortilin in the liver, macrophages, and smooth muscle cells promotes atherosclerotic plaque formation in mice by apparently independent mechanisms [65, 72, 89, 130]. Sortilin was recently identified as a high affinity receptor for PCSK9 [72]. The affinity constant is in the low nanomolar range and close to the actual plasma concentration of PCSK9 [95]. Thus, the sortilin:PCSK9 interaction is up to 100 -fold stronger than the interaction between 
LDLR and PCSK9 [35, 53]. Sortilin consists of a large extracellular domain followed by a single pass transmembrane region and a short cytoplasmic tail harboring sequence motifs for interactions with cytosolic adaptor proteins [66]. Unlike LDLR, sortilin is not destined for lysosomal degradation by PCSK9. Instead, sortilin appears to be involved in intracellular trafficking of PCSK9 as sortilin knockout mice display reduced level of circulating PCSK9, reduced LDL-C, and increased liver LDLR $[72,89]$. On the other hand, viral overexpression of human sortilin in the mouse liver results in increased circulating PCSK9, increased LDL-C, and reduced liver LDLR. Interestingly, PCSK9 binding to sortilin is inhibited by the sortilin propeptide [72]. Since pro-sortilin is converted into its mature form by furin-mediated proteolytic processing in the trans-Golgi network (TGN) [132], it seems unlikely that sortilin and PCSK9 interact in the ER or cis-Golgi. The TGN is the main sorting hub of the cell and proteins may here be destined for constitutive or regulatory secretory vesicles, or to the different endosomal structures [37]. Hence, it is tempting to speculate that sortilin may play a decisive role in the TGN in directing PCSK9 for the secretory pathway in an efficient manner. A recent study reported that sortilin is a target for PCSK9-induced degradation but employed a sortilin variant with a C-terminal myc-tag [20]. The presence of any C-terminal tag in sortilin is known to affect its interaction with cytosolic adaptor proteins and may thus have a relevant effect on its cellular function and fate [33].

Interestingly, PCSK9 serum concentrations correlate positively with the sortilin extracellular domain (ECD) [72] which is released from the cell surface by a disintegrin and metalloproteinase (ADAM) both in a regulated and constitutive manner [50,77]. Whether the sortilin ECD in plasma reflects increased expression levels of sortilin and thereby increased PCSK9 secretion or whether sortilin ECD has a PCSK9 modulatory activity on its own is currently unknown [79]. Interestingly, sortilin ECD acts as potential decoy receptor for the neurotrophic factor progranulin [146]. The expression of sortilin is modulated by a number of factors including diet and exercise, but notably, plasma sortilin ECD correlates with increased body mass index [21].

Taken together, sortilin is a high affinity receptor for PCSK9 that regulates PCSK9 at several levels by facilitating its trafficking in the TGN and possibly as a shedded form in plasma where it may form a complex with PCSK9. Furthermore, sortilin might affect PCSK9 indirectly by affecting cytokine signaling. However, the direction of the regulation is complex as sortilin influences cytokine signaling by several mechanisms and the sortilin effect on PCSK9 may, therefore, dependent on the tissue and the cellular context. Sortilin forms a physical complex with leukemia inhibitory factor (LIF) receptor- $\beta$ and its presence enhances STAT3 phosphorylation induced by helical type I cytokines [97], a pathway that is reported to inhibit PCSK9 expression [24, 159]. Furthermore, sortilin directly affects both endocytosis as well as the secretion of several cytokines and inflammatory mediators from T-cells and macrophages [76, 97, 130].

\section{Extracellular regulation of PCSK9 by proteolytic inactivation}

Mature PCSK9 can be detected in plasma and hepatocyte culture supernatant as a $62 \mathrm{kDa}$ active form and a $55 \mathrm{kDa}$ form with reduced activity towards LDLR. The lower molecular weight form originates from proteolytic processing at $\mathrm{Arg}^{218}$ by the related proprotein convertase furin and to a lesser extent by protein convertase 5 or $6 \mathrm{~A}$ $[13,74]$. This is highly interesting as the naturally occurring GOF PCSK9 variants R218S and F216L display altered proteolytic processing [13]. In the R218S variant with arginine at position 218 substituted for serine, the cleavage site is obstructed and no furin-mediated inactivation is observed. In the case of $\mathrm{F} 216 \mathrm{~L}$, proteolytic inactivation is reduced, possibly because the sequence adjacent to the actual cleavage site no longer fits in the substrate-binding pocket of furin. Accordingly, plasma from homozygous individuals carrying R218S or F216L, respectively, has markedly reduced levels of the $55 \mathrm{kDa}$ form of PCSK9 [49]. From a pharmacological point of view, it is also interesting that fibrates up-regulate furin and possibly increasing proteolytic PCSK9 inactivation [92].

Furin cleavage likely primes PCSK9 for further degradation and thereby elimination from the circulation. Recently, matrix metalloproteinase 2 was also found to proteolytically inactivate PCSK9. However, the physiological relevance of this regulatory effect remains to be established [202].

\section{Clearance mechanisms of plasma PCSK9}

LDL receptor plays a major role in clearance of plasma PCSK9. In wild-type mice, iodinated PCSK9 has a half-life of approximately $5 \mathrm{~min}$, while this is increased to $15 \mathrm{~min}$ in LDLR knockout mice [67]. The radioactivity mainly accumulates in the liver, but a significant portion is found in the kidney [191]. However, PCSK9 is still relatively rapidly removed from the circulation in the absence of LDLR, suggesting the existence of other clearance mechanisms. This is supported by the fact that individuals homozygous for LDLR inactivating mutations have markedly increased LDL-C, but the PCSK9 levels are not correspondingly high [23]. One obvious clearance mechanism is proteolytic degradation of PCSK9 initiated by furin 
as described above. Another proposed PCSK9 clearance receptor is amyloid $\beta$ precursor like protein 2 , but this remains to be established in vivo $[39,40]$.

\section{PCSK9 effects distinct from hepatic LDLR regulation}

Without any doubt, the main overall physiological effect of PCSK9 is that on hepatic expression of LDLR thereby controlling the plasma concentration of LDL-C and indirectly also that of oxidized LDL (oxLDL) [138]. However, hepatic regulation of LDLR by PCSK9 has consequences on other target tissues that respond to LDL-C and oxLDL. Furthermore, PCSK9 is also expressed in extra-hepatic tissues such as heart and kidney. In most extra-hepatic tissues, cellular cholesterol concentration is less dependent on LDLR-driven cholesterol uptake, because most peripheral tissues regulate their cholesterol ester levels by secretion rather than uptake of LDL-C [138]. Nevertheless, extra-hepatic cells express LDLR that might be regulated by PCSK9, too. In extra-hepatic cells, LDL-C and oxLDL are agonists for mainly three different receptors: LDLR, low-density lipoprotein receptor-related protein 1 (LRP$1=\mathrm{CD} 91)$, and lectin-like oxidized LDL receptor 1 (LOX-1). Their endogenous expression is controlled by PCSK9 and the concentrations of their ligands are controlled by PCSK9 as well. Finally, PCSK9 can exert effects that are independent from the surface expression of LDLR as it also interferes with intracellular molecule transport of very low-density lipoprotein (VLDL) receptors, cluster of differentiation 81 (CD81), and epithelial sodium channel $(\mathrm{ENaC})$ [170]. Furthermore, in the intestine, for example, GOF mutations of PCSK9 up-regulate cholesterol transporters NPC1L1 and CD36, thereby increasing cholesterol uptake in an LDLR independent way [106]. In this section, examples for extra-hepatic effects of PCSK9 are briefly summarized and those most relevant for cardiovascular aspects are highlighted. The role of PCSK9 in glycaemic control and diabetes will not be discussed, because the most important findings are already summarized in section "Insulin signaling, diabetes and PCSK9 expression".

\section{PCSK9 and its role in lipopolysaccharide (LPS)- driven inflammation}

Inflammatory processes are involved in a variety of known cardiovascular diseases such as infection, hypertension, atherosclerosis development, and ischemia/reperfusion injury. LRP-1 antagonizes the pro-inflammatory effects of classical triggers of inflammation like LPS and TNF $\alpha$. While activation of plasma membrane-bound LRP-1 depresses nuclear factor kappa-light-chain-enhancer of activated B cells (NFKB) signaling, extracellular LRP-1 activates stress activated kinases like p38 MAP kinase [119]. While the activation of LRP-1 attenuates LPS-driven inflammation, LPS itself increases the expression of PCSK9 and, therefore, decreases the hepatic expression of LDLR $[51,68]$. This leads to increased plasma LDL-C and indirectly oxLDL, as well. oxLDL itself induces a proinflammatory process in macrophages depending on the activation of NFKB pathways. oxLDL increases the expression of PCSK9 in macrophages and the effects of oxLDL on NFKB activation depend on the induction of PCSK9 [188]. On the other hand, PCSK9 inhibits expression and activity of Abcal protein in macrophages, thereby reducing cholesterol efflux of the cell [2]. Collectively, there are different levels at which PCSK9 interferes with the consequences of inflammation and modifies the overall response. For a review about the relationship between inflammation and PCSK9, see Ref. [18].

\section{PCSK9 in vascular cells}

Smooth muscle cells and to a lower extent also endothelial cells constitutively express PCSK9 [42, 52]. The functional relevance is not clear. The vascular expression of PCSK9 is considerable high in regions with low shear stress, i.e., aortic branching regions and may correlate with higher levels of reactive oxygen species (ROS) and inflammation. In patients with acute coronary syndrome, high plasma levels of PCSK9 correlate with inflammation [61]. PCSK9 exerts direct effects on plaque composition [212], specifically on local inflammation and this is independent from LDL-C but related to LDLR expression [63]. Furthermore, platelet count is positively associated with plasma PCSK9 in coronary artery disease (CAD) patients, but the association is lost after adjustment for inflammation, again supporting a role for PCSK9 in inflammation [109].

Direct effects of oxLDL on endothelial cells were analyzed in the context of endogenous regulation of PCSK9 expression. oxLDL-dependent apoptosis was attenuated by siRNA directed against PCSK9 [208]. Furthermore, oxLDL induced the expression of PCSK9 in these cells [208]. Collectively, the data suggest that even in endothelial cells, a cell type that obviously expresses very low levels of PCSK9 and PCSK9 may be causally involved in cellular effects induced by oxLDL.

In summary, PCSK9 may affect atherosclerosis via regulation of LDL-C and oxLDL plasma concentrations. These effects are extensively reviewed, i.e., by Pirillo et al. [144]. Some recent clinical studies have found a correlation between acute coronary syndrome and major adverse cardiovascular events suggesting a clinical relevant relationship between the pro-inflammatory activity of PCSK9 described above and clinical relevant readouts [61, 109]. 


\section{PCSK9 and its role in cardiac physiology and pathophysiology}

There are currently no studies available that clarify a potential role for PCSK9 for the function and adaptation of cardiomyocytes. As already mentioned, PCSK9 indirectly affects cardiomyocytes by modulating the plasma concentrations of LDL-C and oxLDL. As effects of LDL-C and oxLDL on cardiomyocytes are less well reviewed as those to vascular cells, they will be briefly summarized below.

Only few experiments were performed to analyze effects of LDL-C on cardiomyocytes. Cardiomyocytes control their cholesterol homeostasis mainly by regulated cholesterol efflux [150]. However, they express LDLR, but LDLR in cardiomyocytes does not serve mainly as a cholesterol uptake molecule $[113,150]$. Depleting cholesterol concentration in cardiomyocytes by administration of probucol, a cholesterol synthesis inhibitor, interrupts cholesterol/caveolin-1 interaction in the plasma membrane, leading to accelerated degradation of human ether related gogo (hERG) channels, thereby prolonging action potential duration. This effect can be normalized by LDL-C suggesting cholesterol uptake in cardiomyocytes [69]. Adult rabbit cardiomyocytes exposed to LDL-C show slightly increased calcium transients. Mechanistically, this requires transsarcolemmal calcium transport pathways [113]. These experiments suggest that LDL-C may improve cardiac function. On the other hand, at least in atrial-like cardiomyocytes (HL-1 cells, an immortalized cell line with some cardiac-specific differentiation), LDL-C decreases the expression of sarcoplasmatic reticulum (SR) calcium ATPase (SERCA) 2a, ryanodine receptor 2 (RyR2), and connexin-40 within $24 \mathrm{~h}$. This effect of LDL-C reduced calcium transients and slowed conduction velocity in such cells [9]. It remains elusive whether or not this difference is due to time differences between the studies (minutes vs. hours) or due to the source of myocytes (atrial vs. ventricular). Furthermore, the participation of PCSK9 in these effects of LDL-C has not been investigated.

Upon ischemia/reperfusion, cardiomyocytes accumulate cholesterol. In ischemic cardiomyopathy, activation of HIF- $1 \alpha$ leads to up-regulation of LRP-1 $[22,27]$. These receptors, unlike LDLR, seem to be responsible for cholesterol accumulation in cardiomyocytes. Additional cholesterol uptake seems to be achieved by VLDL receptors [142]. LRP-1 is not specific for LDL-C. $\alpha-$ Macroglobulin is another ligand for LRP-1 receptors in cardiomyocytes [139]. From these studies, it is already known that LRP-1 activation causes an activation of p42/ p44 MAP-kinase pathways. Therefore, it must be expected that LDL activates p42/p44 MAP kinase in cardiomyocytes via interaction with LRP-1. LDL-C accelerates proteasomal degradation of dual specific phosphatases DUSP1 and
DUSP6 in cardiomyocytes and thereby increases the amount of phosphorylated p42/p44 MAP kinase [60]. In addition, LRP-1 may directly activate p42/p44 MAP kinase pathways. LRP-1 receptors have an intracellular $\mathrm{PKC} \alpha$ binding domain [110] and $\mathrm{PKC} \alpha$ pathways transiently activate p42/p44 MAP kinase in adult rat ventricular cardiomyocytes [169]. LRP-1 transiently moves to lipid drafts, cholesterol-enriched plasma microdomains that facilitate receptor signaling [158]. The data suggest that LDL-C via activation of LRP-1 receptors initially activates p42/p44 MAP kinase and that this activation is stabilized by induction of proteasomal-dependent degradation of DUSP1 and DUSP6. Of note, p42/p44 MAP kinase activation represses PCSK9 expression in hepatic cells. Extrapolating these data onto cardiomyocytes, activation of LRP-1 by LDL-C may potentially suppress PCSK9 expression.

Within the LRP receptor family, LRP-5 is activated during ischemia in hypercholesteremic animals and increased in its expression. Subsequent activation of the canonical Wnt-signaling pathway may protect against postischemic damage, because LRP-5 knockout mice had larger infarcts compared to wild-type mice [19]. Whether PCSK9 is involved in the myocardial effects of LRP-5 remains to be established.

Effects of oxLDL on cardiomyocytes are highlighted by findings that plasma oxLDL concentrations are associated with decreased cardiac function independent of vascular alterations [153]. Moreover, high oxLDL and high plasma levels of brain natriuretic peptide (BNP) are independent predictors of cardiac mortality [196]. Experiments on HL-1 cells showed that oxLDL induces the expression of BNP and also that of monocyte chemotactic protein (MCP)-1 in vitro [27]. MCP-1 is a well-established downstream target of $\mathrm{NF \kappa B}$, a signal transduction pathway that is involved in pro-inflammatory processes. Of note, LDL-C did not increase the expression of either BNP or MCP-1 in HL-1 cells. Therefore, effects are specific for oxLDL in myocytes and most likely evoked by activation of LOX-1. In addition, exposure of oxLDL to guinea pig cardiomyocytes caused severe electrophysiological and contractile dysfunction in these cells [213]. Again, these effects were not mimicked by LDL-C. Similar to LDL-C, low concentrations of oxLDL increase calcium transients most likely by activating translemmal calcium flux [114].

In cardiomyocytes oxidative stress, agonists of the renin-angiotensin-system (RAS), and oxLDL cooperate together. Angiotensin II induces the expression of BNP, causes cellular hypertrophy, and induces the expression of LOX-1. Activation of NFKB seems to trigger these events and angiotensin effects depend on LOX-1 expression $[82,83]$. A coupling between LOX-1, angiotensin (AT) receptor $1\left(\mathrm{AT}_{1}\right)$ expression, and $\mathrm{AT}_{1}$ activation suggests that LOX-1 is also involved in the onset of cardiac fibrosis 
[116]. Similarly, increasing oxidative stress to H9c2-cells by doxorubicin increases the expression of LOX-1 in cardiomyocyte-like cells. Activation of LOX-1 receptors subsequently induced cellular apoptosis [182]. oxLDL increases further the expression of calcium-sensing receptors (CaSR) that link extracellular calcium to intracellular calcium transients and contractility in cardiomyocytes $[70,168]$. Whether the induction of apoptosis induced by doxorubicin requires an up-regulation and/or activation of CaSR is not known. However, once oxLDL has up-regulated CaSR, the subsequent activation of CaSR may lead to apoptosis. Reperfusion is another pathophysiological scenario leading to an increased expression of LOX-1 in cardiomyocytes. Neutralizing LOX-1 activation during reperfusion by administration of an anti-LOX-1 antibody reduces the infarct size suggesting that reperfusion does not only increase the expression of LOX-1 but also activates these receptors [86]. Collectively, several stress scenarios such as RAS activation, ischemia/reperfusion, and oxidative stress collectively increase the expression of LOX-1 in cardiomyocytes. Again, it remains to be established whether some of these oxLDL-dependent effects require PCSK9. Our unpublished data show that isolated adult rat ventricular cardiomyocytes constitutively express PCSK9 and that oxLDL-dependent effects on cell shortening can be antagonized by neutralizing PCSK9 in cardiomyocytes (Fig. 3). It is tempting to speculate that the aforementioned long-term effects of LDL-C on HL-1 cells on SERCA and RyR expression contribute to these effects. Moreover, it is unlikely that oxLDL directly damages cardiomyocytes [166]. However, oxLDL activates p38 MAP kinase via activation of LOX-1 and this attenuates cell shortening via down-regulation of SERCA [131].

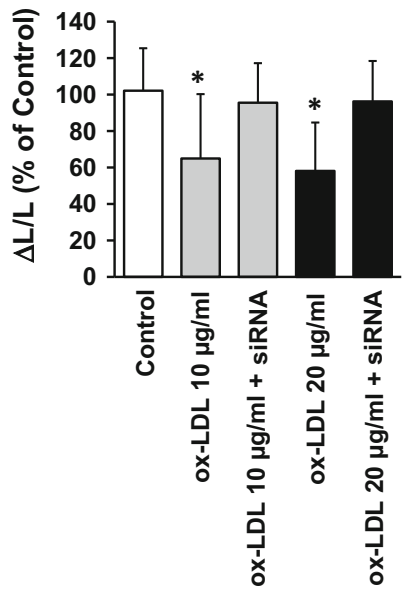

Fig. 3 Effect of siRNA directed against PCSK9 on load-free cells shortening $(\Delta L / L)$ of isolated adult rat ventricular cardiomyocytes exposed to oxLDL. Data are mean \pm SD from $n=90$ cells (10 culture dishes; 2 preparations)
Conclusive remarks about the role of extra-hepatic effects of PCSK9 targeting

In summary, these emerging PCSK9 effects distinct from hepatic LDLR regulation described above need to be replicated and confirmed in humans. In addition, their importance for clinical outcomes will remain a matter of debate for some time for two main reasons: PCSK9-inhibiting antibodies lower LDL-C very potently which is likely the main effect in clinical trials and any extra-hepatic effects have to be established on top of LDL-C lowering. Second, regulatory agencies request that trials with PCSK9 inhibitors (PCSK9i) are performed on optimal statin therapy except for statin-intolerant patients. However, statins may mask some of the proposed effects. Here, comparing low-dose PCSK9i with high-potency statin matched in dose for equal LDL-C lowering may clarify the impact of PCSK9 independent of LDL-C-lowering effects.

\section{Approaches to reduce PCSK9 synthesis and/ or PCSK9/LDLR interaction}

PCSK9 interacts with LDLR intra-end extracellular domains and directs LDLR towards degradation. Therefore, to preserve LDLR expression, either the synthesis of PCSK9 or its interaction with the LDLR needs to be reduced. The interaction of PCSK9 with the LDLR can be attenuated by removing PCSK9 from the circulation (extracellular IgG antibody, monobodies, and vaccination) or offering alternative binding partners rather than LDLR (mimetic peptides) (for review, see Ref. [15]). The synthesis of PCSK9 can be reduced at the level of translation (silencing RNA and oligonucleotides) or its intracellular self-cleavage (mimetic peptides).

A large number of companies are currently involved in PCSK9 inhibitor research at preclinical and clinical trial stages (see https://citeline.com/pcsk9-inhibitors-futurehold-controversial-new-class/).

\section{Approaches targeting extracellular PCSK9/LDLR interaction}

The most advanced approach for reducing LDLR expression is the administration of human monoclonal IgG antibodies and the recent clinical data are discussed later in this review article (see section "Studies of PCSK9-inhibition in patients with high cardiovascular risk"). The effects of PCSK9 antibodies are independent from the circulating PCSK9 concentration [38]. Apart from the therapeutic use of IgG antibodies, smaller molecular scaffolds targeting circulating PCSK9 are in development. This includes the 
development of single domain antibodies and antibodies directed against the catalytic domain of PCSK9 [178, 206].

Adnectins or monobodies are derived from the tenth extracellular type III domain of human fibronectin [112] and have been modified to target PCSK9 without affecting their structural stability [127]. In hypercholesterolemic, overexpressing human PCSK9 transgenic mice, a single intravenous injection of BMS-962476 (Bristol-Myers Squibb/Adnexus) reduced LDL-C and free PCSK9 levels. Treatment of cynomolgus monkeys with BMS-962476 suppressed free PCSK9 $>99 \%$ within $10 \mathrm{~min}$, resulting in reductions in LDL-C by approximately $55 \%$ within $48 \mathrm{~h}$ that persisted for nearly 3 weeks [127].

Vaccines Given the half-life of antibodies regular injections every 2-4 weeks are required. Therefore, peptide [59] or virus-like particle-based vaccines [34] targeting PCSK9 have been developed that stimulate the immune system to generate high-affinity, long-lasting PCSK9specific antibodies. In mice [59] and macaques [34], a long-lasting decrease in circulating LDL-C up to 1 year was measured after application of the vaccines. Pharmaceutical companies (among them are Pfizer and AFFiRiS) developing PCSK9 vaccines already started (AFFiRiS) or will start clinical trials.

Mimetic peptides towards the PCSK9 binding motif on the LDLR (EGF-A) [123, 177, 211], the catalytic domain of PCSK9 [4], the prodomain of PCSK9 [140], and the C-terminal domain of PCSK9 [46] have been developed. A synthetic EGF-A mimetic peptide dose-dependently inhibited PCSK9-induced degradation of LDLR in HepG2 cells [177]. Also binding of PCSK9 to VLDL receptors was effectively inhibited by the synthetic EGF-A peptide [177]. Similarly, LDLR subfragments with a GOF mutation in the EGF-A binding motif (H306Y) blocked the binding of secreted PCSK9 to cell surface LDLR, thereby increasing LDLR expression in HepG2 cells [123]. Other mimetic peptides of 15-amino-acid length directed towards the disulphide loop (Cys323-Cys358) of PCSK9 containing the key GOF mutation D(374)/Y site exhibited a high LDLR promoting activity in both $\mathrm{HepG} 2$ and $\mathrm{HuH}$ cells [4]. As posttranslational modifications of PCSK9 increase its activity, mimetic peptides directed against the epitope phoshpho-Ser47 and sulpho-Y38 of PCSK9 also preserved LDLR levels in HepG2 cells [140]. Screening of phagedisplayed peptide libraries identified a 13-amino-acid linear peptide (Pep2-8) as the smallest PCSK9 inhibitor. Pep2-8 bound to PCSK9 and fully restored LDLR surface levels and LDL particle uptake in PCSK9-treated HepG2 cells [209].

The development of fusion proteins that interact with the prosegment or the catalytic domain of the PCSK9/prosegment complex has been proposed for interference with PCSK9 processing and maturation. A recombinant fusion protein derived from the Fc portion of human $\operatorname{IgG}$ and containing the prosegment of PCSK9 directly bound to human PCSK9 [160]. Coincubation of HepG2 cells with the fusion protein and extracellular PCSK9 significantly attenuated PCSK9-mediated LDLR degradation, providing evidence that the fusion protein interferes with the effect of PCSK9 on LDLR at the extracellular level [160]. In addition, an imidazole-based compound was proven to inhibit PCSK9-LDL-R interaction thereby mediating a hypocholesterolemic effect [187].

PCSK9 binds to annexin A2 which prevents PCSK9directed LDLR degradation in HuH7, HepG2, and Chinese hamster ovary cells [120]. Plasma analyses of annexin A2 knockout mice revealed an approximately $100 \%$ increase in PCSK9 levels and a $40 \%$ increase in LDL cholesterol levels, while adenoviral overexpression of annexin A2 in mouse liver increased LDLR expression in vivo [175]. Structure-function analyses demonstrated that the C-terminal cysteine-histidine-rich domain of PCSK9 interacts specifically with the $\mathrm{N}$-terminal repeat R1 of annexin A2. Mutational analysis of this 70-amino-acid-long repeat indicated that the RRTKK81 sequence of annexin A2 is implicated in this binding, because its mutation to AATAA81 prevents its interaction with PCSK9 [120]. Thus, application of small mimetic peptides related to annexin A2 has also been proposed as a potential approach for PCSK9 inhibition [175].

Finally, a small peptide that impedes normal PCSK9 folding (SX-PCK9, Serometrix), thus hindering its binding to LDL receptors, is currently being studied.

Taken together-Small peptides directed against variable parts of PCSK9 reduce its interaction with the LDLR, thereby reducing LDL-C. Small peptides may offer the advantage of being orally applicable. However, there are no clinical trials testing the use of small peptides to inhibit PCSK9 at this time.

Interestingly, in this context, a cholesteryl ester transfer protein (CETP) inhibitor (K-312, Kowa) developed to primarily enhance HDL cholesterol also significantly reduced LDL-C in rabbits [128]. The mechanism identified in LDL-C reduction was a significant down-regulation of PCSK9. In addition, some natural occurring compounds might inhibit PCSK9 expression, such as lupin peptides or polydatin [96, 205].

\section{Genom editing and oligonucleotide-based therapeutics targeting intra- and extracellular PCSK9}

Using a CRISPR-associated (Cas) 9 genome-editing system to target the human PCSK9 gene in implanted human hepatocytes in mice revealed a significant down-regulation of PCSK9 in hepatocytes and the circulating blood [203]. 
Oligonucleotide-based therapeutics include short interfering RNA (siRNA), that degrade target mRNA, antisense oligonucleotides, that may be working through RNAsemediated mRNA decay and oligonucleotides-induced alternative splicing.

siRNA-PCSK9 silencing RNA (siRNA) was formulated in a lipidoid nanoparticle (LNP, Alnylam Pharmaceuticals). Liver-specific siRNA silencing of PCSK9 in mice and rats reduced PCSK9 mRNA levels by 50-70\%. The reduction in PCSK9 transcript was associated with up to a $60 \%$ reduction in plasma LDL-C levels. In nonhuman primates, a single dose of siRNA targeting PCSK9 resulted in a rapid, durable, and reversible lowering of plasma PCSK9 and LDL-C lasting for 3 weeks after a single intravenous administration [56]. Silencing of the SREBP cleavage activating protein in rhesus monkeys reduces PCSK 9 expression by $75 \%$ leading to a $50 \%$ reduction in LDL-C [80].

The siRNA (ALN-PCS) was tested subsequently in a dose-finding study in 32 healthy participants with an LDLC above $3 \mathrm{mmol} / \mathrm{L}$, ALN-PCS administered intravenously resulted in dose-dependent reductions in plasma PCSK9 and LDL-C levels, with the highest dose conferring 70 and $40 \%$ reductions in PCSK9 and LDL-C levels, respectively, an effect which was sustained for 2-3 weeks after administration. Overall, ALN-PCS was well tolerated with side effects being similar to placebo [54]. Alnylam has recently another phase I clinical trial testing subcutaneously administered ALN-PCS demonstrating a sustained reduction of PCSK9 and LDL-C for up to 180 days after a single injection [55]. The long-term effect is related to stabilization of the siRNA [201].

Antisense oligonucleotides (ASO) ASOs are short, single-stranded complementary sequences of nucleotides inhibiting protein synthesis by binding to the target mRNA inhibiting protein translation. ASO offers high specificity, but like monoclonal antibodies require intravenous or subcutaneous routes of administration. Two PCSK9-ASOs were initially explored in preclinical trials (for review, see Ref. [172]), but development was stopped after a phase I clinical trial (http://www.clinicaltrials.gov; NCT01082562) because of safety concerns [172].

Nucleic acid analogs that contain at least one monomer in locked conformation (LNA) provide a higher binding affinity and specificity to the target mRNA [88]. LNA ASO reduced the mRNA and protein levels of PCSK9 with a concomitant increase in LDLR protein levels after transfection in HepG2 and $\mathrm{HuH} 7$ cells. In mice, tail vein intravenous administration of LNA ASO reduced the level of PCSK 9 mRNA by approximately $60 \%$, an effect lasting more than 16 days. Hepatic LDLR protein levels were significantly up-regulated threefold for at least 8 days and approximately twofold for 16 days [71]. In nonhuman primates, LNA ASO targeting PCSK9 produced a sustained reduction of LDL-C after a loading dose and four weekly maintenance doses. PCSK9 mRNA and serum PCSK9 protein were reduced by $85 \%$ which resulted in a $50 \%$ reduction in circulating LDL-C [111].

Although promising preclinical data are available, the first phase I clinical trial testing the efficacy of SPC5001 (Santaris Pharma) - an ASO with locked RNA nucleotides on both ends of the DNA — was terminated for undisclosed reasons (http://www.clinicaltrials.gov; NCT01350960). One potential explanation for study termination relates to renal side effects, since SPC5001 administered subcutaneously in one volunteer increased creatine levels, white blood cells, granular casts, and caused minimal hematuria on urine microscopy. Kidney biopsy showed multifocal tubular necrosis and signs of oligonucleotide accumulation, all changes being reversible upon termination of SPC5001 administration [198, 199]. Recently, a small molecule compound (R-IMPP) was identified which inhibit translocation of PCSK9 at the level of the 80S ribosome; however, data on the efficiency of such approach for LDL-C management are lacking [143].

Splice-switching oligonucleotides (SSO) are a new approach to inactivate PCSK9 converting the normal splice form to a natural, less abundant, and inactive, splice variant. Following administration of SSO, an increase of the selected splice form at both the mRNA and protein level was detected when compared to nontreated Huh7 and HepG2 cell lines, with a concomitant increase of the LDL$\mathrm{R}$ protein level. In vivo, full conversion to the splice form was achieved in a reporter system when mice were treated with the specific SSO [156].

Taken together-a number of approaches targeting both intra- and extracellular PCSK9 are under development, some of which passed from the preclinical into clinical testing (siRNA), while others failed (OSA, LNA). Since PCSK9 has multiple intracellular targets [171] one has to see whether long-term results of intra- and extracellular reduction of PCSK9 are advantageous as compared to the extracellular reduction of PCSK9 only.

\section{Possible pleiotropic effects of targeting PCSK9 and interaction with statins}

A recent meta-analysis of $>300,000$ participants from 49 trials calculated a relative risk reduction for major vascular events per $1 \mathrm{mmol} / \mathrm{L}(38.7 \mathrm{mg} / \mathrm{dL})$ reduction in LDL-C level of 0.77 for statins and 0.75 for diet, bile acid sequestrants, ileal bypass, and ezetimibe [181]. The authors conclude that "the use of statin and nonstatin therapies that act via up-regulation of LDL-R expression to reduce LDL$\mathrm{C}$ was associated with similar risk reductions of major vascular events per change in LDL-C". The relative 
contribution of the cholesterol-independent (or "pleiotropic") effects of statins for clinical outcomes remains a matter of debate for two main reasons: pleiotropic statin effects are mediated by inhibition of isoprenoids which correlate in humans with LDL-C lowering and are, therefore, hard to quantify. Second, contemporary trials of nonstatin medications, such as the Niemann-Pick C1-like 1 protein inhibitor ezetimibe and the PCSK9 inhibitors, are performed on a statin background. As pointed out in our review, interesting extra-hepatic and/or LDL-C independent effects of PCSK9-inhibition have been described. However, we suspect that - if confirmed in humans-the quantification of their relative clinical importance will face the same challenges as the concept of statin pleiotropy. Some, but not all of these issues, could be addressed by comparing low-dose PCSK9 inhibition with high-potency statin matched in dose for equal LDL-C lowering.

\section{Studies of PCSK9-inhibition in patients with high cardiovascular risk}

The fully human PCSK9-binding antibodies evolocumab and alirocumab have been approved by the FDA (US Food and Drug Administration) and the EMA (European Medicines Agency) in 2015. Both drugs have been tested in high cardiovascular risk patients on top of maximally tolerated statin treatment. Taken together, these studies report an additional reduction of LDL-C (as well as nonHDL and ApoB) by $50-60 \%$ and a reduction of lipoprotein $L p(a)$ by 25-30\% [28]. HDL-C and triglycerides are not significantly reduced. The cholesterol content is reduced in the subfractions LDL1, LDL2, and LDL3 +4 as well as the apolipoproteins CII and CIII and the cholesterol content of very low-density, intermediate-density, and remnant lipoproteins [194]. Studies such as ODYSSEY CHOICE or LAPLACE confirm that the effect of PCSK9 inhibitor is additive to other oral lipid-lowering therapies [184]. The additive effect is consistent with the mechanism of action and the up-regulation of PCSK9 serum concentrations by both statins and fibrates [121].

The available data on safety do not reveal a statistical significant signal [155]. However, further analysis of the ongoing outcome studies is needed to fully assess safety. A potential problem of long-term antibody treatment is the occurrence of autoantibodies. Evolocumab and alirocumab are fully human antibodies and, therefore, theoretically less likely to induce autoantibodies compared to humanized therapeutic antibodies. Only very few cases of anti-drug antibodies have been published to date and no reduction of LDL-C lowering or an off-target effect has been reported, but this topic requires long-term observation [98]. Indeed, the global development program for a third PCSK9 inhibitor, bococizumab, that was tested in large clinical outcome trials, was discontinued because of an unanticipated attenuation of the LDL-C lowering over time, as well as a higher level of immunogenicity and higher rate of injection-site reactions with bococizumab compared to alirocumab and evolocumab [151, 152]. Bococizumab is a humanized antibody that apparently induced more antidrug antibodies (ADA) compared to the two approved fully human antibodies. Inhibiting ADA can cause a loss of efficacy and very likely contribute to injection-site reactions. Therefore, the topic of ADA will remain important for the future long-term surveillance of the class [98].

Statin-associated muscle symptoms (SAMS) represent a clinical problem that can limit the maximally tolerated dose of a statin [99, 100, 185]. ODYSSEY ALTERNATIVE (alirocumab) and GAUSS-2 (evolocumab) and GAUSS-3 [137, 154] tested PCSK9-antibodies in this complex patient population and found a consistent $50-60 \%$ LDL-C lowering response which was superior to ezetimibe.

\section{Studies of PCSK9-inhibition in patients with familial hypercholesterolemia (FH)}

Familial hypercholesterolemia $(\mathrm{FH})$ is a common autosomal inherited condition characterized by a very high risk of atherosclerotic diseases mediated by high LDL-C. FH is under-diagnosed and under-treated [197]. Recent studies have reported the effects of alirocumab and evolocumab in the setting of heterozygous FH (heFH). In RUTHERFORD-2 (Reduction of LDL-C With PCSK9 Inhibition in Heterozygous Familial Hypercholesterolemia Disorder Study-2), treatment with evolocumab against a background of statin/ezetimibe resulted in decreases in LDL-C of $50-60 \%$ [57]. LDL-C lowering in heFH was similar irrespective of LDLR mutation status. Data from the ODYSSEY HIGH and the ODYSSEY familial hypercholesterolemia I and II studies with alirocumab showed a similar LDL-C reduction [85]. TESLA (Trial Evaluating PCSK9 Antibody in Subjects With LDL Receptor Abnormalities) [58] and TAUSSIG (Trial Assessing long term USe of PCSK9 Inhibition in Subjects wIth Genetic LDL Disorders) [147] test evolocumab in rare patients with homozygous familial on top of maximally tolerated oral lipid-lowering therapy. As expected from the mechanism of action of PCSK9-inhibition, a range of in LDL-C reduction was observed in LDLR-defective patients and no reduction was seen in LDLR negative patients. Interestingly, $\mathrm{Lp}$ (a) was found to be reduced in LDL-R negative patients suggesting mechanisms independent of the hepatic LDLR [183]. The ongoing HAUSER (Trial Assessing Efficacy, Safety and Tolerability of PCSK9 Inhibition in Paediatric Subjects With Genetic LDL 
Disorders) addressed the important population of patients aged 10-17 years (Clinical Trials Identifier NCT02392559).

To date, lipoprotein apheresis is the only remaining treatment option for individuals with severe FH. The ODYSSEY ESCAPE study (Study of Alirocumabin Patients With Heterozygous Familial Hypercholesterolemia Undergoing Low-density Lipoprotein (LDL) Apheresis Therapy) showed that alirocumab biweekly injection to standard treatment reduced apheresis frequency, the primary efficacy end point, by $75 \%$ vs. those who received placebo plus standard therapy [129]. The need for any apheresis treatment at all was completely abolished in $63 \%$ of the alirocumab group vs. none of the placebo group.

\section{Cardiovascular events assessed in safety studies}

The ODYSSEY LONGTERM study randomized 2341 patients at high risk for cardiovascular events receiving statins to alirocumab or placebo [100]. At week 24, LDL-C was reduced by $62 \%$. The alirocumab group, as compared with the placebo group, had higher rates of injection-site reactions (5.9 vs. $4.2 \%$ ), myalgia (5.4 vs. $2.9 \%$ ), neurocognitive events (1.2 vs. $0.5 \%)$, and ophthalmologic events (2.9 vs. $1.9 \%)$ [100]. In a post hoc analysis, the rate of major adverse cardiovascular events (death from coronary heart disease, nonfatal myocardial infarction, fatal or nonfatal ischemic stroke, or unstable angina requiring hospitalization) was lower with alirocumab than with placebo (1.7 vs. $3.3 \%$, hazard ratio $0.52,95 \%$ confidence interval 0.31-0.90, nominal $P=0.02$ ).

The open-label, randomized OSLER program enrolled 4465 patients who had completed 1 of 12 phase 2 or 3 studies of evolocumab [162]. Evolocumab reduced LDL-C by $61 \%$. After a median observation time of 11.1 months, adverse events occurred with similar frequency compared to placebo, although neurocognitive events were reported more frequently in the evolocumab group. The rate of cardiovascular events at 1 year was reduced from $2.18 \%$ in the standard therapy group to $0.95 \%$ in the evolocumab group (hazard ratio in the evolocumab group 0.47, 95\% confidence interval $0.28-0.78, P=0.003$ ) [162]. This effect was mainly driven by a reduction of coronary revascularizations.

A potential problem of long-term antibody treatment is the occurrence of autoantibodies. Evolocumab and alirocumab are fully human antibodies and, therefore, theoretically less likely to induce autoantibodies compared to humanized therapeutic antibodies. Only very few cases of anti-drug antibodies have been published to date and no reduction of LDL-C lowering or an off-target effect has been reported, but this topic requires long-term observation [98, 193].
An important conclusion of OSLER and ODYSSEY LONGTERM relates to the striking homogeneity of the results of these two programs using different antibodies. Both studies show a very similar and potent LDL-C reduction, are well tolerated, and report a positive signal with regard to cardiovascular events.

A pooled post hoc analysis from ten double-blind alirocumab trials included 4974 patients, of which 104 patients experienced a major adverse cardiovascular event (MACE) [149]. For every $39 \mathrm{mg} / \mathrm{dL}$ lower achieved LDL-C, the risk of MACE was $24 \%$ diminished. Percent reductions in LDL-C from baseline were inversely correlated with MACE rates [HR $0.71(0.57-0.89)$ per additional 50\% reduction from baseline] including individuals with very low levels of LDL-C $(<50 \mathrm{mg} / \mathrm{dL})$.

The recent GLAGOV study tested the effects of PCSK9 inhibition with evolocumab on progression of coronary atherosclerosis in statin-treated 968 patients with coronary artery disease measured by serial intracoronary ultrasonography (IVUS) imaging [135]. LDL-C was $36.6 \mathrm{mg} /$ $\mathrm{dL}$ in the statin + evolocumab group vs. $93.0 \mathrm{mg} / \mathrm{dL}$ in the statin group. The PCSK9i evolocumab met its primary end point with a reduction in percent atheroma volume for evolocumab $(-0.95 \%)$ but not placebo $(+0.05 \%)$ and a greater percentage of patients demonstrating plaque regression (64.3 vs. $47.3 \%)$ after 76 weeks. Post hoc analysis examining the relationship between achieved LDL-C level and change in percent atheroma volume showed a linear reduction down to very low LDL-C levels of $20 \mathrm{mg} / \mathrm{dL}$. No safety signals were observed in the GLAGOV study.

\section{Endpoint trials with PCSK9 inhibiting antibodies}

The two most important open questions with regard to PCSK9 inhibitor relate to their effects on clinical outcomes and the long-term safety. FOURIER (Further Cardiovascular OUtcomes Research with PCSK9 Inhibition in Subjects with Elevated Risk) is a multinational Phase 3 doubleblind, randomized, placebo-controlled trial in $27,564 \mathrm{sec}-$ ondary prevention patients who had either myocardial infarction, an ischemic stroke or symptomatic peripheral artery disease on optimized statin therapy [161] (Fig. 4). Patients were randomized to receive evolocumab s.c. $140 \mathrm{mg}$ every 2 weeks or $420 \mathrm{mg}$ monthly or placebo. LDL-C was lowered from $92 \mathrm{mg} / \mathrm{dL}(2.4 \mathrm{mM} / \mathrm{L})$ in the statin group to $30 \mathrm{mg} / \mathrm{dL}(0.78 \mathrm{mM} / \mathrm{L})$ in the patients receiving PCSK9i. Compared to placebo, evolocumab reduced the composite of cardiovascular death, myocardial infarction, or stroke from 7.4 to $5.9 \%$ (HR $0.80,95 \%$ CI $0.73-0.88, P<0.001)$. The results were consistent across key subgroups, including the subgroup of patients in the lowest quartile for baseline LDL cholesterol levels. There 


\begin{tabular}{|c|c|c|}
\hline Characteristic & FOURIER & ODYSSEY \\
\hline Population & $\begin{array}{l}\text { Patients } \mathbf{4} \text { to } \mathbf{5 2} \text { wks post ACS } \\
\text { - LDL-C } \geq 70(1.8) \\
\text { (on atorva } 40-80 \mathrm{mg} \text { or rosuva } 20-40 \mathrm{mg} \text { ) }\end{array}$ & $\begin{array}{l}\text { History of clinically evident CVD: MI, } \\
\text { stroke or symptomatic PAD and } \geq 1 \text { major } \\
\text { RF or } \geq 2 \text { minor RFs } \\
\cdot \text { LDL-C } \geq 70(1.8) \text { or } \\
\text { - non-HDL-C } \geq 100(2.6) \\
\text { (on atorva } 20-80 \mathrm{mg} \text { or equivalent) }\end{array}$ \\
\hline Primary Endpoints & $\begin{array}{l}\text { - } \text { CV death, } \\
\text { - MI, } \\
\text { - All stroke, } \\
\text { - Urgent admission with UA, } \\
\text { - Revascularization }\end{array}$ & $\begin{array}{l}\text { - Coronary heart disease death, } \\
\text { - Non-fatal MI, } \\
\text { - Fatal/non-fatal Ischemic stroke, } \\
\text { - Unstable Angina requiring hospitalization }\end{array}$ \\
\hline No. of Primary EP & 3550 & 1,613 \\
\hline Power & $>99 \%$ for $\mathrm{HR} 0.85$ & $90 \%$ for HR 0.85 \\
\hline First Secondary Endpoint & $\begin{array}{l}\text { - CV death, } \\
\text { - MI, } \\
\text { - All stroke }\end{array}$ & $\begin{array}{l}\text { - Coronary death, } \\
\text { - MI, } \\
\text { - Urgent admission with UA, } \\
\text { - Ischemia driven revascularization }\end{array}$ \\
\hline No. of 1st Secondary EP & 1,630 & $\sim 3,000$ \\
\hline Power & $\sim 90 \%$ for HR 0.85 & $>90 \%$ \\
\hline
\end{tabular}

Fig. 4 Ongoing large cardiovascular outcome trials in secondary prevention with PCSK9-inhibiting antibodies. The drugs are applied subcutaneously. The recruitment of ODYSSEY outcomes and

was no significant difference between the study groups with regard to adverse events (including new-onset diabetes), with the exception of injection-site reactions, which were more common with evolocumab (2.1 vs. $1.6 \%$ ). Neurocognitive endpoints were specifically assessed in the EBBINGHAUS (Evaluating PCSK9 Binding antiBody

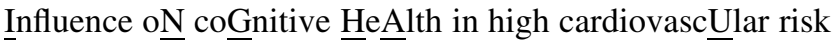
Subjects) involving approximately 1900 patients enrolled in the FOURIER outcomes study. The study showed no differences with regard to executive function (Spatial Working Memory strategy index) and secondary endpoints of working memory, memory function, and psychomotor speed [62].

An important second very large outcome trial testing the PCSK9 inhibitor alirocumab, ODYSSEY OUTCOMES $(\sim 18,000$ patients recently hospitalized for ACS, NCT01663402), is fully recruited (Fig. 4). The results are expected to be reported in 2018. Together with the FOURIER results, these data will provide a definitive basis for the assessment of the risk and the benefit of this young class of drugs and novel scientific information, e.g., with regard to very low LDL-C serum concentrations.

\section{Compliance with ethical standards}

Conflict of interest Authors received honoraria from Amgen (R.S., K.D.S, U.L.), Astra Zeneca (R.S.), MSD (U.L.), Recordati (R.S.), and Sanofi (R.S., U.L.) for lecturing.
FOURIER has been completed. The studies are event driven. LDL$\mathrm{C}$ values are depicted in $\mathrm{mg} / \mathrm{dL}(\mathrm{mM} / \mathrm{L}) . C V$ cardiovascular, $M I$ myocardial infarction, $U A$ unstable angina

Open Access This article is distributed under the terms of the Creative Commons Attribution 4.0 International License (http://crea tivecommons.org/licenses/by/4.0/), which permits unrestricted use, distribution, and reproduction in any medium, provided you give appropriate credit to the original author(s) and the source, provide a link to the Creative Commons license, and indicate if changes were made.

\section{References}

1. Abifadel M, Varret M, Rabes JP, Allard D, Ouguerram K, Devillers M, Cruaud C, Benjannet S, Wickham L, Erlich D, Derre A, Villeger L, Farnier M, Beucler I, Bruckert E, Chambaz J, Chanu B, Lecerf JM, Luc G, Moulin P, Weissenbach J, Prat A, Krempf M, Junien C, Seidah NG, Boileau C (2003) Mutations in PCSK9 cause autosomal dominant hypercholesterolemia. Nat Genet 34:154-156. doi:10.1038/ng1161

2. Adorni MP, Cipollari E, Favari E, Zanotti I, Zimetti F, Corsini A, Ricci C, Bernini F, Ferri N (2017) Inhibitory effect of PCSK9 on Abca1 protein expression and cholesterol efflux in macrophages. Atherosclerosis. doi:10.1016/j.atherosclerosis.2016.11. 019

3. Ai D, Chen C, Han S, Ganda A, Murphy AJ, Haeusler R, Thorp E, Accili D, Horton JD, Tall AR (2012) Regulation of hepatic LDL receptors by mTORC1 and PCSK9 in mice. J Clin Invest 122:1262-1270. doi:10.1172/JCI611919

4. Alghamdi RH, O'Reilly P, Lu C, Gomes J, Lagace TA, Basak A (2015) LDL-R promoting activity of peptides derived from human PCSK9 catalytic domain (153-421): design, synthesis and biochemical evaluation. Eur J Med Chem 92:890-907. doi:10.1016/j.ejmech.2015.01.022 
5. Al-Mashhadi RH, Sorensen CB, Kragh PM, Christoffersen C, Mortensen MB, Tolbod LP, Thim T, Du Y, Li J, Liu Y, Moldt B, Schmidt M, Vajta G, Larsen T, Purup S, Bolund L, Nielsen LB, Callesen H, Falk E, Mikkelsen JG, Bentzon JF (2013) Familial hypercholesterolemia and atherosclerosis in cloned minipigs created by DNA transposition of a human PCSK9 gain-offunction mutant. Sci Transl Med 5:166ra1. doi:10.1126/sci translmed.3004853

6. Athyros VG, Tziomalos K, Doumas M, Sfikas G, Karagiannis A (2017) The effect of proproteien conervates subtilisin(kexin type 9 and its inhibition on glucose metabolism and cardiovascular risk. We should do better the second time after statins. Curr Pharm Des (Epub ahead of print)

7. Aulchenko YS, Ripatti S, Lindqvist I, Boomsma D, Heid IM, Pramstaller PP, Penninx BW, Janssens AC, Wilson JF, Spector T, Martin NG, Pedersen NL, Kyvik KO, Kaprio J, Hofman A, Freimer NB, Jarvelin MR, Gyllensten U, Campbell H, Rudan I, Johansson A, Marroni F, Hayward C, Vitart V, Jonasson I, Pattaro C, Wright A, Hastie N, Pichler I, Hicks AA, Falchi M, Willemsen G, Hottenga JJ, de Geus EJ, Montgomery GW, Whitfield J, Magnusson P, Saharinen J, Perola M, Silander K, Isaacs A, Sijbrands EJ, Uitterlinden AG, Witteman JC, Oostra BA, Elliott P, Ruokonen A, Sabatti C, Gieger C, Meitinger T, Kronenberg F, Döring A, Wichmann HE, Smit JH, McCarthy MI, van Duijn CM, Peltonen L, ENGAGE Consortium (2009) Loci influencing lipid levels and coronary heart disease risk in 16 European population cohorts. Nat Genet 41:47-55. doi:10.1038/ng.269

8. Awan Z, Dubuc G, Faraj M, Dufour R, Seidah NG, Davignon J, Rabasa-Lhoret R, Baass A (2014) The effect of insulin on circulating PCSK9 in postmenopausal obese women. Clin Biochem 47:1033-1039. doi:10.1016/j.clinbiochem.2014.03.022

9. Barriga M, Cal R, Cabello N, Llach A, Vallmitjana A, Benitez R, Badimon L, Cinca J, Llorente-Cortes V, Hove-Madsen L (2013) Low densities lipoproteins promote unstable calcium handling accompanied by reduced SERCA2 and connexin- 40 expression in cardiomyocytes. PLoS One 8:e58128. doi:10. 1371/journal.pone.0058128

10. Bauer RC, Yenilmez BO, Rader DJ (2015) Tribbles-1: a novel regulator of hepatic lipid metabolism in humans. Biochem Soc Trans 43:1079-1084. doi:10.1042/BST20150101

11. Benjannet S, Hamelin J, Chretien M, Seidah NG (2012) Lossand gain-of-function PCSK9 variants: cleavage specificity, dominant negative effects, and low density lipoprotein receptor (LDLR) degradation. J Biol Chem 287:33745-33755. doi:10. 1074/jbc.M112.399725

12. Benjannet S, Rhainds D, Essalmani R, Mayne J, Wickham L, Jin W, Asselin MC, Hamelin J, Varret M, Allard D, Trillard M, Abifadel M, Tebon A, Attie AD, Rader DJ, Boileau C, Brissette L, Chretien M, Prat A, Seidah NG (2004) NARC-1/PCSK9 and its natural mutants: zymogen cleavage and effects on the low density lipoprotein (LDL) receptor and LDL cholesterol. J Biol Chem 279:48865-48875. doi:10.1074/jbc.M409699200

13. Benjannet S, Rhainds D, Hamelin J, Nassoury N, Seidah NG (2006) The proprotein convertase (PC) PCSK9 is inactivated by furin and/or PC5/6A: functional consequences of natural mutations and post-translational modifications. J Biol Chem 281:30561-30572. doi:10.1074/jbc.M606495200

14. Benjannet S, Saavedra YG, Hamelin J, Asselin MC, Essalmani R, Pasquato A, Lemaire P, Duke G, Miao B, Duclos F, Parker R, Mayer G, Seidah NG (2010) Effects of the prosegment and $\mathrm{pH}$ on the activity of PCSK9: evidence for additional processing events. J Biol Chem 285:40965-40978. doi:10.1074/jbc.M110. 154815

15. Bergeron N, Phan BA, Ding Y, Fong A, Krauss RM (2015) Proprotein convertase subtilisin/kexin type 9 inhibition: a new therapeutic mechanism for reducing cardiovascular disease risk. Circulation 132:1648-1666. doi:10.1161/CIRCULATIONAHA

16. Bjorklund MM, Hollensen AK, Hagensen MK, Dagnaes-Hansen F, Christoffersen C, Mikkelsen JG, Bentzon JF (2014) Induction of atherosclerosis in mice and hamsters without germline genetic engineering. Circ Res 114:1684-1689. doi:10.1161/ CIRCRESAHA.114.302937

17. Boggild S, Molgaard S, Glerup S, Nyengaard JR (2016) Spatiotemporal patterns of sortilin and SorCS2 localization during organ development. BMC Cell Biol 17:8. doi:10.1186/s12860016-0085-9

18. Bonaventura A, Carbone F, Vecchié A, Dallegri F, Camici GG, Montecucco F, Liberale L (2017) Treatment with proprotein convertase subtilisin/kexin type 9 (PCSK9) Inhibitors to reduce cardiovascular inflammation and outcomes. Curr Med Chem. doi:10.2174/0929867324666170303123734

19. Borrell-Pages M, Vilahur G, Romero JC, Casani L, Bejar MT, Badimon L (2016) LRP5/canonical Wnt signalling and healing of ischemic myocardium. Basic Res Cardiol 111:67. doi:10. 1007/s00395-016-0585-y

20. Butkinaree C, Canuel M, Essalmani R, Poirier S, Benjannet S, Asselin MC, Roubtsova A, Hamelin J, Marcinkiewicz J, Chamberland A, Guillemot J, Mayer G, Sisodia SS, Jacob Y, Prat A, Seidah NG (2015) Amyloid precursor-like protein 2 and sortilin do not regulate the PCSK9 convertase-mediated low density lipoprotein receptor degradation but interact with each other. J Biol Chem 290:18609-18620. doi:10.1074/jbc.M115. 647180

21. Buttenschon HN, Demontis D, Kaas M, Elfving B, Molgaard S, Gustafsen C, Kaerlev L, Petersen CM, Børglum AD, Mors O, Glerup S (2015) Increased serum levels of sortilin are associated with depression and correlated with BDNF and VEGF. Transl Psychiatry 5:e677. doi:10.1038/tp.2015.167

22. Cal R, Juan-Babot O, Brossa V, Roura S, Galvez-Monton C, Portoles M, Rivera M, Cinca J, Badimon L, Llorentes-Cortes V (2012) Low density lipoprotein receptor-related protein 1 expression correlates with cholesteryl ester accumulation in the myocardium of ischemic cardiomyopathy patients. J Transl Med 10:160. doi:10.1186/1479-5876-10-160

23. Cameron J, Bogsrud MP, Tveten K, Strom TB, Holven K, Berge KE, Leren TP (2012) Serum levels of proprotein convertase subtilisin/kexin type 9 in subjects with familial hypercholesterolemia indicate that proprotein convertase subtilisin/kexin type 9 is cleared from plasma by low-density lipoprotein receptor-independent pathways. Transl Res 160:125-130. doi:10.1016/j.trsl.2012.01.010

24. Cao A, Wu M, Li H, Liu J (2011) Janus kinase activation by cytokine oncostatin M decreases PCSK9 expression in liver cells. J Lipid Res 52:518-530. doi:10.1194/jlr.M010603

25. Caresky HE, Davis RA, Alborn WE, Troutt JS, Cao G, Konrad RJ (2008) Atorvastatin increases human serum levels of proprotein convertase subtilisin/kexin type 9. J Lipid Res 49:394-398. doi:10.1194/jlr.M700437-JLR200

26. Cariou B, Langhi C, Le Bras M, Bartolotti M, Le KA, Theytaz F, Le May C, Guyomarc'h-Delasalle B, Zaïr Y, Kreis R, Boesch C, Krempf M, Tappy L, Costet P (2013) Plasma PCSK9 concentrations during an oral fat load and after short term high-fat, high-fat high-protein and high-fructose diets. Nutr Metab (Lond) 10:4. doi:10.1186/1743-7075-10-4

27. Chandrakala AN, Sukul D, Selvarajan K, Sai-Sudhakar C, Sun B, Parthasarathy S (2012) Induction of brain natriuretic peptide and monocyte chemotactic protein-1 gene expression by oxidized low-density lipoprotein: relevance of ischemic heart failure. Am J Physiol Cell Physiol 302:C165-C177. doi:10.1152/ ajpcel1/00116.2011 
28. Chapman MJ, Stock JK, Ginsberg NH (2015) PSCK9 inhibitors and cardiovascular disease: heralding a new therapeutic era. Curr Opin Lipidol 26:511-520. doi:10.1097/MOL. 0000000000000239

29. Chen XW, Wang H, Bajaj K, Zhang P, Meng ZX, Ma D, Bai Y, Liu HH, Adams E, Baines A, Yu G, Sartor MA, Zhang B, Yi Z, Lin J, Young SG, Schekman R, Ginsburg D (2013) SEC24A deficiency lowers plasma cholesterol through reduced PCSK9 secretion. eLife 2:e0444. doi:10.7554/eLife.00444

30. Cohen JC, Boerwinkle E, Mosley TH Jr, Hoobs HH (2006) Sequence variations in PCSK9, low LDL, and protection against coronary heart disease. N Eng J Med 354:1264-1272. doi:10. 1056/NEJMoa054013

31. Cohen J, Pertsemlidis A, Kotowski IK, Graham R, Garcia CK, Hobbs HH (2005) Low LDL cholesterol in individuals of African descent resulting from frequent nonsense mutations in PCSK9. Nat Genet 37:161-165. doi:10.10138/ng.1509

32. Costet P, Cariou B, Lambert G, Lalanne F, Lardeux B, Jarnoux AL, Grefhorst A, Staels B, Krempf M (2006) Hepatic PCSK9 expression is regulated by nutritional status via insulin and sterol regulatory element-binding protein $1 \mathrm{c}$. J Biol Chem 281:6211-6218. doi:10.1074/jbcM.508582200

33. Cramer JF, Gustafsen C, Behrens MA, Oliveira CL, Pedersen JS, Madsen P, Petersen CM, Thirup SS (2010) GGA autoinhibition revisited. Traffic 11:259-273. doi:10.1111/j.1600-0854. 2009.01017.x

34. Crossey E, Amar MJ, Sampson M, Peabody J, Schiller JT, Chackerian B, Remaley AT (2015) A cholesterine-lowering VLP vaccine that targets PCSK9. Vaccine 33:5747-5755. doi:10.1016/j.vaccine.2015.09.044

35. Cunningham D, Danley DE, Geoghegan DF, Griffor MC, Hawkins JL, Subashi TA, Varghese AH, Ammirati MJ, Culp JS, Hoth LR, Mansour MN, McGrath KM, Seddon AP, Shenolikar S, Stutzman-Engwall KJ, Warren LC, Xia D, Qiu X (2007) Structural and biophysical studies of PCSK9 and its mutants linked to familial hypercholesterolemia. Nat Struct Mol Biol 14:413-419. doi:10.1038/nsmb1235

36. Dancourt J, Barlowe C (2010) Protein sorting receptors in the early secretory pathway. Annu Rev Biochem 79:777-802. doi:10.1146/annurev-biochem-061608-091319

37. De Matteis DA, Luini A (2008) Exiting the Golgi complex. Nat Rev Mol Cell Biol 9:273-284. doi:10.1038/nrm2378

38. Desai NR, Giugliano RP, Wasserman SM, Gibbs JP, Liu T, Scott R, Sabatine MS (2017) Association between circulating baseline proprotein convertase subtilisin/kexin type 9 levels and efficacy of evolocumab. JAMA Cardiol. doi:10.1001/jama cardio.2016.5395

39. DeVay RM, Shelton DL, Liang H (2013) Characterization of proprotein convertase subtilisin/kexin type 9 (PCSK9) trafficking reveals a novel lysosomal targeting mechanism via amyloid precursor-like protein 2 (APLP2). J Biol Chem 288:10805-10818. doi:10.1074/jbcM.113.001969

40. DeVay RM, Yamamoto L, Shelton DL, Liang H (2015) Common proprotein convertase subtilisin/kexin type 9 (PCSK9) epitopes mediate multiple routes for internalization and function. PLoS One 10:e125127. doi:10.1371/journal.pone. 0125127

41. Ding Q, Strong A, Patel KM, Ng S-L, Gosis BS, Regan SN, Cowan CA, Rader DJ, Musunuru K (2014) Permanent alteration of PCSK9 with in vivo CRISPR-Cas9 genome editing. Circ Res 115:488-492. doi:10.1161/CIRCRESAHA.115.304351/-/DC1

42. Ding Z, Liu S, Wang X, Deng X, Fan Y, Sun C, Wang Y, Mehta JL (2015) Hemodynamic shear stress via ROS modulates PCSK9 expression in human vascular endothelial and smooth muscle cells and along the mouse aorta. Antioxid Redox Signal 22:760-771. doi:10.1089/ars.2014.6054
43. Dong B, Singh AB, Azhar S, Seidah NG, Liu J (2015) Highfructose feeding promotes accelerated degradation of hepatic LDL receptor and hypercholesterolemia in hamsters via elevated circulating PCSK9 levels. Atherosclerosis 239:364-374. doi:10. 1016/j.atherosclerosis.2015.01.013

44. Dong B, Singh AB, Shende VR, Liu J (2017) Heepatic HNF1 transcription factors control the induction of PCSK9 mediated by rosuvastatin in normolipidemic hamsters. Int $\mathbf{J}$ Mol Med 39:749-756. doi:10.3892/ijmm.2017.2879

45. Dong B, Wu M, Li H, Kraemer FB, Adeli K, Seidah NG, Park SW, Liu J (2010) Strong induction of PCSK9 gene expression through HNF1alpha and SREBP2: mechanism for the resistance of LDL-cholesterol lowering effect of statins in dyslipidemic hamsters. J Lipid Res 51:1486-1495. doi:10.1194/jlr.M003556

46. Du F, Hui Y, Zhang M, Linton MF, Fazio S, Fan DJ (2011) Novel domain interacton regulates secretion of proprotein convertase subtilisin/kexin type 9 (PCSK9) protein. J Biol Chem 286:43054-43061. doi:10.1074/jbc.M111.273474

47. Duan Y, Chen Y, Hu W, Li X, Yang X, Zhou X, Yin Z, Kong D, Yao Z, Hajjar DP, Liu L, Liu Q, Han J (2012) Peroxisome proliferator-activated receptor gamma activation by ligands and dephosphorylation induces proprotein convertase subtilisin kexin type 9 and low density lipoprotein receptor expression. J Biol Chem 287:23667-23677. doi:10.1074/jbc.M112.350181

48. Dubuc G, Chamberland A, Wassef H, Davignon J, Seidah NG, Bernier L, Prat A (2004) Statins upregulate PCSK9, the gene encoding the proprotein convertase neural apoptosis-regulated convertase-1 implicated in familial hypercholesterolemia. Arterioscler Thromb Vasc Biol 24:1454-1459. doi:10.1161/01. ATV.0000134621.14315.43

49. Essalmani R, Susan-Resiga D, Chamberland A, Abifadel M, Creemers JW, Boileau C, Seidah NG, Prat A (2011) In vivo evidence that furin from hepatocytes inactivates PCSK9. J Biol Chem 286:4257-4263. doi:10.1074/jbc.M110.192104

50. Evans SF, Irmady K, Ostrow K, Kim T, Nykjaer A, Saftig P, Blobel C, Hempstaed BL (2011) Neuronal brain-derived neurotrophic factor is synthesized in excess, with levels regulated by sortilin-mediated trafficking and lysosomal degradation. J Biol Chem 286:29556-29567. doi:10.1074/jbc.M111.219675

51. Feingold KR, Moser AH, Shigenaga JK, Patzek SM, Grunfeld C (2008) Inflammation stimulates the expression of PCSK9. Biochem Biophys Res Commun 374:341-344. doi:10.1016/j.bbrc. 2008.07.023

52. Ferri N, Tibolla G, Pirillo A, Cipollone F, Mezzetti A, Pacia S, Corsini A, Catapano AL (2012) Proprotein convertase subtilisin kexin type 9 (PCSK9) secreted by cultured smooth muscle cells reduced macrophage LDLR levels. Atherosclerosis 220:381-386. doi:10.1016/j.athrosclerosis.2011.11.026

53. Fisher TS, Lo Surdo P, Pandit S, Mattu M, Santoro JC, Wisniewski D, Cummings RT, Calzetta A, Cubbon RM, Fischer PA, Tarachandini A, De FR, Wright SD, Sparrow SP, Carfi A, Sitlani A (2007) Effects of $\mathrm{pH}$ and low density lipoprotein (LDL) on PCSK9-dependent LDL receptor regulation. J Biol Chem 282:20502-20512. doi:10.1074/jbc.M701634200

54. Fitzgerald K, Frank-Kamenetsky M, Shulga-Morskaya S, Liebow A, Bettencourt BR, Sutherland JE, Hutabarat RM, Clausen VA, Karsten V, Cehelsky J, Nichur SV, Kotelianski V, Horton J, Mant T, Chiesa J, Ritter J, Munisamy M, Vaishnaw AK, Gollob JA, Simon A (2014) Effect of an RNA interference drug on the synthesis of proprotein convertase subtilisin/kexin type 9 (PCSK9) and the concentration of serum LDL cholesterol in healthy volunteers: a randomised, single-blind, placebo-controlled, phase 1 trial. Lancet 383:60-68. doi:10.1016/S01406736(13)61914-5

55. Fitzgerald K, White S, Borodovsky A, Bettencourt BR, Strahs A, Clausen V, Wijngaard P, Horton JD, Taubel J, Brooks A, 
Fernando C, Kauffman RS, Kallend D, Vaishnaw A, Simon A (2016) A highly durable RNAi therapeutic inhibitor of PCSK9. N Engl J Med 376:41-51. doi:10.1056/NEJMoa1609243

56. Frank-Kamenetsky M, Grefhorst A, Anderson NN, Racie TS, Bramlage B, Akinc A, Butler D, Charisse K, Dorkin R, Fan Y, Gamba-Vitalo C, Hadwiger P, Jayaraman M, John M, Jayaprakash KN, Maier M, Nechev L, Rajeev KG, Read T, Rohl I, Soutschek J, Tan P, Wong J, Wang G, Zimmermann T, de Fougerolles A, Vornlocher HP, Langer R, Anderson DG, Manoharan M, Koteliansky V, Horton JD, Fitzgerald K (2008) Therapeutic RNAi targeting PCSK9 acutely lowers plasma cholesterol in rodents and LDL cholesterol in nonhuman primates. Proc Natl Acad Sci USA 105:11915-11920. doi:10.1073/ pnas.0805434105

57. Frederick JR, Stein EA, Dufour R, Turner T, Civeira F, Burgess L, Langslet G, Scott R, Olsson AG, Sullivan D, Hovingh GK, Cariou B, Gouni-Berthold I, Somaratne R, Bridges I, Scott R, Wasserman SM, Gaudet D, for the RUTHERFORD-2 Investigators (2015) PCSK9 inhibition with evolocumab (AMG 145) in heterozygous familial hypercholesterolaemia (RUTHERFORD2): a randomized, double-blind, placebo-controlled trial. Lancet 385:331-340. doi:10.1016/S0140-6736(14)61399-4

58. Frederick JR, Honarpour N, Blom DJ, Hovingh GK, Xu F, Scott $\mathrm{R}$, Wasserman SM, Stein EA, for the TELSA Investigators (2015) Inhibition of PCSK9 with evolocumab in homozygous hypercholesterolaemia (TESLA part B): a randomised, doubleblind, placebo-controlled trial. Lancet 385:341-350. doi:10. 1016/S0140-6736(14)61374-X

59. Galabova G, Brunner S, Winsauer G, Juno C, Wanko B, Mairhofer A, Lührs P, Schneeberger A, von Bonin A, Mattner F, Schmidt W, Staffler G (2014) Peptide-based anti-PCSK9 vaccines-an approach for long-term LDLc management. PLoS One 9:e114469. doi:10.1371/journal.pone.0114469

60. Geetha N, Mihaly J, Stockenhuber A, Blasi F, Uhrin P, Binder BR, Freissmuth M, Breuss JM (2011) Signal integration and coincidence detection in the mitogen-activated protein kinase/ extracellular signal-regulated kinase (ERK) cascade. J Biol Chem 286:25663-25674. doi:10.1074/jbc.M111.221903

61. Gencer B, Montecucco F, Nanchen D, Carbone F, Klingenberg R, Vuilleumier N, Aghlmandi S, Heg D, Räber L, Auer R, Jüni P, Windecker S, Lüscher TF, Matter CM, Rodondi N, Mach F (2016) Prognostic value of PCSK9 levels in patients with acute coronary syndrome. Eur Heart J 37:546-553. doi:10.1093/eur heartj/ehv637

62. Giugliano RP, Mach F, Zavitz K, Kurtz C, Schneider J, Wang H, Keech A, Pedersen TR, Sabatine MS, Sever PS, Honarpour N, Wasserman SM, Ott BR, EBBINGHAUS Investigators (2017) Design and rationale of the EBBINGHAUS trial: a phase 3, double-blind, placebo-controlled, multicenter study to assess the effect of evolocumab on cognitive function in patients with clinically evident cardiovascular disease and receiving statin background lipid-lowering therapy-A cognitive study of patients enrolled in the FOURIER trial. Clin Cardiol 40:59-65. doi:10. $1002 /$ clc. 22678

63. Giunzioni I, Tavori H, Covarrubias R, Major AS, Ding L, Zhang Y, DeVay RM, Hong L, Fan D, Predazzi IM, Rashid S, Linton MF, Fazio S (2016) Local effects of human PCSK9 on the atherosclerotic lesion. J Pathol 238:52-62. doi:10.1002/path. 4630

64. Global Lipids Genetics Consortium; Willer CJ, Schmidt EM, Sengupta S, Peloso GM, Gustafsson S, Kanoni S, Ganna A, Chen J, Buchkovich ML, Mora S, Beckmann JS, Bragg-Gresham JL, Chang HY, Demirkan A, Den Hertog HM, Do R, Donnelly LA, Ehret GB, Esko T, Feitosa MF, Ferreira T, Fischer K, Fontanillas P, Fraser RM, Freitag DF, Gurdasani D, Heikkilä K, Hyppönen E, Isaacs A, Jackson AU, Johansson A, Johnson T,
Kaakinen M, Kettunen J, Kleber ME, Li X, Luan J, Lyytikäinen LP, Magnusson PK, Mangino M, Mihailov E, Montasser ME, Müller-Nurasyid M, Nolte IM, O'Connell JR, Palmer CD, Perola M, Petersen AK, Sanna S, Saxena R, Service SK, Shah S, Shungin D, Sidore C, Song C, Strawbridge RJ, Surakka I, Tanaka T, Teslovich TM, Thorleifsson G, Van den Herik EG, Voight BF, Volcik KA, Waite LL, Wong A, Wu Y, Zhang W, Absher D, Asiki G, Barroso I, Been LF, Bolton JL, Bonnycastle LL, Brambilla P, Burnett MS, Cesana G, Dimitriou M, Doney AS, Döring A, Elliott P, Epstein SE, Eyjolfsson GI, Gigante B, Goodarzi MO, Grallert H, Gravito ML, Groves CJ, Hallmans G, Hartikainen AL, Hayward C, Hernandez D, Hicks AA, Holm H, Hung YJ, Illig T, Jones MR, Kaleebu P, Kastelein JJ, Khaw KT, Kim E, Klopp N, Komulainen P, Kumari M, Langenberg C, Lehtimäki T, Lin SY, Lindström J, Loos RJ, Mach F, McArdle WL, Meisinger C, Mitchell BD, Müller G, Nagaraja R, Narisu N, Nieminen TV, Nsubuga RN, Olafsson I, Ong KK, Palotie A, Papamarkou T, Pomilla C, Pouta A, Rader DJ, Reilly MP, Ridker PM, Rivadeneira F, Rudan I, Ruokonen A, Samani N, Scharnagl H, Seeley J, Silander K, Stancáková A, Stirrups K, Swift AJ, Tiret L, Uitterlinden AG, van Pelt LJ, Vedantam S, Wainwright $\mathrm{N}$, Wijmenga $\mathrm{C}$, Wild $\mathrm{SH}$, Willemsen $\mathrm{G}$, Wilsgaard T, Wilson JF, Young EH, Zhao JH, Adair LS, Arveiler D, Assimes TL, Bandinelli S, Bennett F, Bochud M, Boehm BO, Boomsma DI, Borecki IB, Bornstein SR, Bovet P, Burnier M, Campbell H, Chakravarti A, Chambers JC, Chen YD, Collins FS, Cooper RS, Danesh J, Dedoussis G, de Faire U, Feranil AB, Ferrières J, Ferrucci L, Freimer NB, Gieger C, Groop LC, Gudnason V, Gyllensten U, Hamsten A, Harris TB, Hingorani A, Hirschhorn JN, Hofman A, Hovingh GK, Hsiung CA, Humphries SE, Hunt SC, Hveem K, Iribarren C, Järvelin MR, Jula A, Kähönen M, Kaprio J, Kesäniemi A, Kivimaki M, Kooner JS, Koudstaal PJ, Krauss RM, Kuh D, Kuusisto J, Kyvik KO, Laakso M, Lakka TA, Lind L, Lindgren CM, Martin NG, März W, McCarthy MI, McKenzie CA, Meneton P, Metspalu A, Moilanen L, Morris AD, Munroe PB, Njølstad I, Pedersen NL, Power C, Pramstaller PP, Price JF, Psaty BM, Quertermous T, Rauramaa R, Saleheen D, Salomaa V, Sanghera DK, Saramies J, Schwarz PE, Sheu WH, Shuldiner AR, Siegbahn A, Spector TD, Stefansson K, Strachan DP, Tayo BO, Tremoli E, Tuomilehto J, Uusitupa M, van Duijn CM, Vollenweider P, Wallentin L, Wareham NJ, Whitfield JB, Wolffenbuttel BH, Ordovas JM, Boerwinkle E, Palmer CN, Thorsteinsdottir U, Chasman DI, Rotter JI, Franks PW, Ripatti S, Cupples LA, Sandhu MS, Rich SS, Boehnke M, Deloukas P, Kathiresan S, Mohlke KL, Ingelsson E, Abecasis GR (2013) Discovery and refinement of loci associated with lipid levels. Nat Genet 45:1274-1283. doi:10.1038/ng.2797

65. Goettsch C, Hutcheson JD, Aikawa M, Iwata H, Pham T, Nykjaer A, Kjolby M, Rogers M, Michel T, Shibasaki M, Hagita S, Kramann R, Rader DJ, Libby P, Singh SA, Aikawa E (2016) Sortilin mediates vascular calcification via its recruitment into extracellular vesicles. J Clin Invest 126:1323-1336. doi:10. 1172/JCI80851

66. Glerup S, Nykjaer A, Vaegter CB (2014) Sortilins in neurotrophic factor signaling. Handb Exp Pharmacol 220:165-189. doi:10.1007/978-3-642-45106-5_7

67. Grefhorst A, McNutt MC, Lagace TA, Horton JD (2008) Plasma PCSK9 preferentially reduces liver LDL receptors in mice. J Lipid Res 49:1303-1311. doi:10.1194/jlr.M800027-JLR200

68. Grune J, Meyborg H, Bezhaeva T, Kappert K, Hillmeister P, Kintscher U, Pieske B, Stawowy P (2017) PCSK9 regulates the chemokine receptor CCR2 on monocytes. Biochem Biophys Res Commun 485:312-318. doi:10.1016/j.bbrc.2017.02.085

69. Guo J, Li X, Shallow H, Xu J, Yang T, Massaeli H, Li W, Sun T, Pierce GN, Zhang S (2011) Involvement of caveolin in 
probecul-induced reduction in hERG plasma-membrane expression. Mol Pharmacol 79:806-813. doi:10.1124/mol.110. 069419

70. Guo J, Li HZ, Zhang WH, Wang LC, Wang LN, Zhang L, Li GW, Li HX, Yang BF, Wu L, Wang R, Xu CQ (2010) Increased expression of calcium-sensing receptors induced by ox-LDL amplifies apoptosis of cardiomyocytes during simulated ischemia-reperfusion. Clin Exp Pharmacol Physiol 37:e128-e135. doi:10.1111/j.1440-1681.2010.05345.x

71. Gupta N, Fisker N, Asselin MC, Lindholm M, Rosenbohm C, Orum H, Elmen J, Seidah NG (2010) A locked nucleic acid antisense oligonucleotide (LNA) silences PCSK9 and enhances LDLR expression in vitro and in vivo. PLoS One 5:e10682. doi:10.1371/journal.pone.0010682

72. Gustafsen C, Kjolby M, Nyegaard M, Mattheisen M, Lundhede J, Buttenschon H, Mors O, Bentzon JF, Madsen P, Nykjaer A, Glerup S (2014) The hypercholesterolemia-risk gene SORT1 facilitates PCSK9 secretion. Cell Metab 19:310-318. doi:10. 1016/j.cemt.2013.12.006

73. Hampton EN, Knuth MW, Li J, Harris JL, Leslie SA, Spraggon G (2007) The self-inhibited structure of full-length PCSK9 at 1.9 A reveals structural homology with resistin within the C-terminal domain. Proc Natl Acad Sci USA 104:14604-14609. doi:10.1073/pnas.0703402104

74. Han B, Eacho PI, Knierman MD, Troutt JS, Konrad RJ, Yu X, Schroeder KM (2014) Isolation and characterization of the circulating truncated form of PCSK9. J Lipid Res 55:1505-1514. doi:10.1194/jlr.M049346

75. Hasan H, Attlee A, Raiganvar V, Madkour M, Awadallah S (2017) Proprotein convertase subtilisin/kexin type 9 (PCSK9) and metabolic syndrome components among young adult females. Diabetes Metab Syndr. doi:10.1016/j.dsx.2017.03.012

76. Herda S, Raczkowski F, Mittrucker HW, Willimsky G, Gerlach K, Kühl AA, Breiderhoff T, Willnow TE, Dörken B, Höpken UE, Rehm A (2012) The sorting receptor Sortilin exhibits a dual function in exocytic trafficking of interferon-gamma and granzyme $A$ in $\mathrm{T}$ cells. Immunity 37:854-866. doi:10.1016/j. immuni.2012.07.012

77. Hermey G, Sjogaard SS, Petersen CM, Nykjaer A, Gliemann J (2006) Tumour necrosis factor alpha-converting enzyme mediates ectodomain shedding of Vps10p-domain receptor family members. Biochem J 395:285-293. doi:10.1042/BJ20051364

78. Holla OL, Strom TB, Cameron J, Berge KE, Leren TP (2010) A chimeric LDL receptor containing the cytoplasmic domain of the transferrin receptor is degraded by PCSK9. Mol Genet Metab 99:149-156. doi:10.1016/j.ymgme.2009.09.012

79. Hu D, Yang Y, Peng DQ (2017) Increased sortilin and its independent effect on circulating proprotein convertase subtilisin/kexin type 9 (PCSK9) in statin-naive patients with coronary artery disease. Int $\mathrm{J}$ Cardiol 227:61-65. doi:10.1016/j.ijcard. 2016.11.064

80. Jensen KK, Tadin-Strapps M, Wang SP, Hubert J, Kan Y, Ma Y, McLaren DG, Previs SF, Herath KB, Mahsut A, Liaw A, Wang S, Stout SJ, Keohan C, Forrest G, Coelho D, Yendluri S, Williams S, Koser M, Bartz S, Akinsanya KO, Pinto S (2016) Dosedependent effects of siRNA-mediated inhibition of SCAP on PCSK9, LDLDR and plasma lipids in mouse and rhesus monkey. J Lipid Res. doi:10.1194/jlr.M071498

81. Jeong HJ, Lee HS, Kim KS, Kim YK, Yoon D, Park SW (2008) Sterol-dependent regulation of proprotein convertase subtilisin/ kexin type 9 expression by sterol regulatory element-binding protein-2. J Lipid Res 49:399-409. doi:10.1194/jlr;700443. JLR200

82. Kang BY, Khan JA, Ryu S, Shekhar R, Seung K-B, Mehta JL (2010) Curcumin reduces angiotensin-II mediated cardiomyocytes growth via LOX-1 inhibition. J Cardiovasc Pharmacol 55:417-424. doi:10.1097/FJC.0b013e3181ca4ba1

83. Kang BY, Wang W, Palade P, Sharma SG, Mehta JL (2009) Cardiac hypertrophy during hypercholesterolemia and its amelioration with rosuvastatin and amlodipine. J Cardiovasc Pharmacol 54:327-334. doi:10.1097/FJC.0.013e3181b76713

84. Kapelle PJ, Lambert G, Dullaart RP (2011) Plasma proprotein convertase subtilisin-kexin type 9 does not change during $24 \mathrm{~h}$ insulin infusion in healthy subjects and type 2 diabetic patients. Arterosclerosis 214:432-435. doi:10.1016/j.atherosclerosis. 2010.10.028

85. Kastelein JJP, Ginsberg HN, Langslet G, Hovingh GK, Ceska R, Dufour R, Blom D, Civeira F, Krempf M, Lorenzato C, Zhao J, Pordy R, Baccara-Dinet MT, Gipe DA, Geiger MJ, Farnier M (2015) ODYSSEY FH I and FH II: 78 week results with alirocumab treatment in 735 patients with heterozygous familial hypercholesterolaemia. Eur Heart J 36:2996-3003. doi:10.1093/ eurheartj/ehv370

86. Kataokoa K, Hasegawa K, Sawamura T, Fujita M, Yanazume T, Iwai-Kanai E, Kawamura T, Hirai T, Kita T, Nohara R (2003) LOX-1 pathway affects the extent of myocardial ischemiareperfusion injury. Biochem Biophys Res Commun 300:656-660. doi:10.1016/S0006-291X(02)02905-4

87. Kathiresan S, Melander O, Guiducci C, Surti A, Burtt NP, Rieder MJ, Cooper GM, Roos C, Voight BF, Havulinna AS, Wahlstrand B, Hedner T, Corella D, Tai ES, Ordovas JM, Berglund G, Vartiainen E, Jousilahti P, Hedblad B, Taskinen MR, Newton-Cheh C, Salomaa V, Peltonen L, Groop L, Altshuler DM, Orho-Melander M (2008) Six new loci associated with blood low-density lipoprotein cholesterol, high-density lipoprotein cholesterol or triglycerides in humans. Nat Genet 40:189-197. doi:10.1038/ng.75

88. Kauppinen S, Vester B, Wengel J (2005) Locked nucleic acid (LNA): high affinity targeting of RNA for diagnosis and therapeutics. Drug Discov Today Technol 2:287-290. doi:10.1016/j. ddtec.2005.08.012

89. Kjolby M, Andersen OM, Breiderhoff T, Fjorback AW, Pedersen KM, Madsen PO, Jansen P, Heeren J, Willnow TE, Nykjaer A (2010) Sort1, encoded by the cardiovascular risk locus $1 \mathrm{p} 13.3$, is a regulator of hepatic lipoprotein export. Cell Metab 12:213-223. doi:10.1016/j.cmet.2010.08.006

90. Kjolby M, Nielsen MS, Petersen CM (2015) Sortilin, encoded by the cardiovascular risk gene SORT1, and its suggested functions in cardiovascular disease. Curr Atheroscler Rep 17:496. doi:10.1007/s11883-015-0496-7

91. Kosenko T, Golder M, Leblond G, Weng W, Lagace TA (2013) Low density lipoprotein binds to proprotein convertase subtilisin/kexin type-9 (PCSK9) in human plasma and inhibits PCSK9-mediated low density lipoprotein receptor degradation. J Biol Chem 288:8279-8288. doi:10.1074/jbc.M112.421370

92. Kourimate S, Le May C, Langhi C, Jarnoux AL, Ouguerram K, Zair Y, Nguyen P, Krempf M, Cariou B, Costet P (2008) Dual mechanisms for the fibrate-mediated repression of proprotein convertase subtilisin/kexin type 9. J Biol Chem 283:9666-9673. doi:10.1074/jbc.M705831200

93. Krysa JA, Ooi TC, Proctor SD, Vine DF (2017) Nutritional and lipid modulation of PCSK9: effects on cardiometabolic risk factors. J Nutr. doi:10.3945/jn.235069

94. Kwon HJ, Lagace TA, McNutt MC, Horton JD, Deisenhofer J (2008) Molecular basis for LDL receptor recognition by PCSK9. Proc Natl Acad Sci USA 105:1820-1825. doi:10.1073/pnas. 0712064105

95. Lakoski SG, Lagace TA, Cohen JC, Horton JD, Hobbs HH (2009) Genetic and metabolic determinants of plasma PCSK9 levels. J Clin Endocrinol Metab 94:2537-2543. doi:10.1210/jc.2009-0141 
96. Lammi C, Zanoni C, Aiello G, Arnoldi A, Grazioso G (2016) Lupin peptides modulate the protein-protein interaction of PCSK9 with the low density lipoprotein receptor in HepG2 cells. Sci Rep. doi:10.1038/srep29931

97. Larsen JV, Hansen M, Moller B, Madsen P, Scheller J, Nielsen M, Petersen CM (2010) Sortilin facilitates signaling of ciliary neurotrophic factor and related helical type 1 cytokines targeting the gp130/leukemia inhibitory factor receptor beta heterodimer. Mol Cell Biol 30:4175-4187. doi:10.1128/MCB.00274-10

98. Laufs U, Parhofer KG (2015) Simplified algorithm to facilitate communication of familial hypercholesterolaemia. Eur Heart $\mathbf{J}$ 36:3004-3006. doi:10.1093/eurheartj/ehv441

99. Laufs U, Scharnagl H, Halle M, Windler E, Endres M, März W (2015) Treatment options for statin-associated muscle symptoms. Dtsch Arztebl Int 112:748-755. doi:10.3238/arztebl.2015. 0748

100. Laufs U, Scharnagl H, März W (2015) Statin intolerance. Curr Opin Lipidol 26:492-501. doi:10.1097/MOL.0000000000000236

101. Laugier-Robiolle S, Verges B, Le Bras M, Gand E, Bouillet B, Saulnier PJ, Le May C, Pichelin M, Marechaud S, Petit JM, Hadiad S, Cariou B (2017) Glycaemic control influences the relationship between plasma PCSK9 and LDL cholesterol in type 1 diabetes. Diabetes Obes Metab 19:448-451. doi:10.1111/ dom.12819

102. Lebeau P, Al-Hashimi A, Sood S, Lhotak S, Yu P, Gyulay G, Pare G, Chen SR, Trigatti B, Prat A, Seidah NG, Austin RC (2017) Endoplasmatic reticulum stress and $\mathrm{Ca}^{2+}$ depletion differentially modulate the sterol regulatory protein PCSK9 to control lipid metabolism. J Biol Chem 229:1510-1523. doi:10. 1074/jbc.M116.744235

103. Leren TP (2004) Cascade genetic screening for familial hypercholesterolemia. Clin Genet 66:483-487. doi:10.1111/j.13990004-2004.00320.x

104. Levenson AE, Milliren CE, Biddinger SB, Ebbeling CB, Feldman HA, Ludwig DS, de Ferranti SD (2017) Calorically restricted diets decrease PCSK9 in overweight adolescents. Nutr Metab Cardiovasc Dis. doi:10.1016/j.numecd.2016.12.010

105. Levenson AE, Shah AS, Khoury PR, Kimball TR, Urbina EM, de Ferranti SD, Maahs DM, Dolan LM, Wadwa RP, Biddinger SB (2017) Obesity and type 2 diabetes are associated with elevated PCSK9 leevels in young women. Pediatr Diabetes. doi:10.1111/pedi.12490

106. Levy E, Ben Djoudi Ouadda A, Spahis S, Sane AT, Garofalo C, Grenier E, Emonnot L, Yara S, Couture P, Beaulieu JF, Menard D, Seidah NG, Elchebly M (2013) PCSK9 plays a significant role in cholesterol homeostasis and lipid transport in intestinal epithelial cells. Atherosclerosis 227:297-306. doi:10.1016/j. atherosclerosis.2013.01.023

107. Li H, Dong B, Park SW, Lee H-S, Chen W, Liu J (2009) Hepatocyte nuclear factor 1alpha plays a critical role in PCSK9 gene transcription and regulation by the natural hypocholesterolemic compound berberine. J Biol Chem 284:28885-28895. doi:10.1074/jbc.M109.052407

108. Li H, Liu J (2012) The novel function of HINFP as a co-activator in sterol-regulated transcription of PCSK9 in HepG2 cells. Biochem J 443:757-768. doi:10.1042/BJ20111645

109. Li S, Zhu CG, Guo YL, Xu RX, Zhang Y, Sun J, Li JJ (2015) The relationship between the plasma PCSK9 levels and platelets indices in patients with stable coronary artery disease. J Atheroscl Thromb 22:76-84. doi:10.5551/jat.25841

110. Lillis AP, van Duyn LB, Murphy-Ullrich JE, Strickland DK (2008) LDL-related receptor protein 1: unique tissue-specific functions revealed by selective gene knockout studies. Physiol Rev 88:887-918. doi:10.1152/physrev.00033.2007

111. Lindholm MW, Elmen J, Fisker N, Hansen HF, Persson R, Moller MR, Rosenbohm C, Orum H, Straarup EM, Koch T
(2012) PCSK9 LNA antisense oligonucleotides induce sustained reduction of LDL cholesterol in nonhuman primates. Mol Ther 20:376-381. doi:10.1038/mt.2011.260

112. Lipovsek D (2011) Adnectins: engineered target-binding protein therapeutics. Protein Eng Design Select 24:3-9. doi:10.1093/ protein/gzq097

113. Liu K, Pierce GN (1993) The effects of low density lipoprotein on calcium transients in isolated rabbit cardiomyocytes. J Biol Chem 268:3767-3775

114. Liu K, Pierce GN (1993) The action of oxidized low density lipoprotein on calcium transients in isolated rabbit cardiomyocytes. J Biol Chem 268:4145-4151

115. Lo Surdo P, Bottomley MJ, Calzetta A, Settembre EC, Cirillo A, Pandit S, Ni YG, Hubbard B, Sitlani A, Carfí A (2011) Mechanistic implications for LDL receptor degradation from the PCSK9/LDLR structure at neutral pH. EMBO Rep 12:1300-1305. doi:10.1038/embor.2011.205

116. Lü J, Mehta JL (2011) LOX-1: a critical player in the genesis and progression of myocardial ischemia. Cardiovasc Drugs Ther 25:431-440. doi:10.1007/s10557-011-6329-1

117. Ma D, Liu T, Chang L, Rui C, Xiao Y, Li S, Hogenesch JB, Chen YE, Lin JD (2015) The liver clock controls cholesterol homeostasis through Trib1 protein-mediated regulation of PCSK9/low density lipoprotein receptor (LDL-R) axis. J Biol Chem 290:31003-31012. doi:10.1074/jbc.M115.685982

118. Maxwell KN, Breslow JL (2004) Adenoviral-mediated expression of Pcsk9 in mice results in a low-density lipoprotein receptor knockout phenotype. Proc Natl Acad Sci USA 101:7100-7105. doi:10.1073/pnas.0402133101

119. May P (2013) The low-density lipoprotein receptor-related protein 1 in inflammation. Curr Opin Lipidol 24:134-137. doi:10.1097/MOL.0b013e32835e809c

120. Mayer G, Poirier S, Seidah NG (2008) Annexin A2 is a C-terminal PCSK9-binding protein that regulates endogenous low density lipoprotein receptor levels. J Biol Chem 283:31791-31801. doi:10.1074/jbc.M805971200

121. Mayne J, Dewpura T, Raymond A, Cousins M, Chaplin A, Lahey KA, Lahaye SA, Mbikay M, Ooi TC, Chretien M (2008) Plasma PCSK9 levels are significantly modified by statins and fibrates in humans. Lipids Health Dis 7:22. doi:10.1186/1476-511X-7-22

122. Mbikay M, Sirois F, Mayne J, Wang G-S, Chen A, Dewpura T, Prat A, Seidah NG, Chretien M, Scott FW (2010) PCSK9-deficient mice exhibit impaired glucose tolerance and pancreatic islet abnormalities. FEBS Lett 584:701-706. doi:10.1016/j.febs let.2009.12.018

123. McNutt MC, Kwon HJ, Chen C, Chen JR, Horton JD, Lagace TA (2009) Antagonism of secreted PCSK9 increases low density lipoprotein receptor expression in HepG2 cells. J Biol Chem 284:10561-10570. doi:10.1074/jbc.M808802200

124. Melone M, Wilsie L, Palyha O, Strack A, Rashid S (2012) Discovery of a new role of human resistin in hepatocyte lowdensity lipoprotein receptor suppression mediated in part by proprotein convertase subtilisin/kexin type 9. J Am Coll Cardiol 59:1697-1705. doi:10.1016/j.jacc.2011.11.064

125. Miao J, Manthena PV, Haas ME, Ling AV, Shin DJ, Graham MJ, Crooke RM, Liu J, Biddinger SB (2015) Role of insulin in the regulation of proprotein convertase subtilisin/kexin type 9 . Arterioscler Thromb Vasc Biol 35:1589-1596. doi:10.1161/ ATVBAHA.115.305688

126. Miranda MX, van Tits LJ, Lohmann C, Arsiwala T, Winnik S, Tailleux A, Stein S, Gomes AP, Suri V, Ellis JL, Lutz TA, Hottiger MO, Sinclair DA, Auwerx J, Schoonjans K, Staels B, Lüscher TF, Matter CM (2015) The Sirt1 activator Sirt3025 provides atheroprotection in $\mathrm{ApoE}^{-1-}$ mice by reducing hepatic PCSK9 secretion and enhancing LDL-R expression. Eur Heart J 36:51-59. doi:10.1093/eurheartj/ehu095 
127. Mitchell T, Chao G, Sitkoff D, Lo F, Monshizadegan H, Meyers D, Low S, Russo K, DiBella R, Denhez F, Gao M, Myers J, Duke G, Witmer M, Miao B, Ho SP, Khan J, Parker RA (2014) Pharmacologic profile of the adnectin BMS-962476, a small protein biologic alternative to PCSK9 antibodies for low-density lipoprotein lowering. J Pharmacol Exp Ther 350:412-424. doi:10.1124/jpet.114.214221

128. Miyosawa K, Watanabe Y, Murakami K, Murakami T, Shibata H, Iwashita M, Yamazaki H, Yamazaki K, Ohgiya T, Shibuya K, Mizuno K, Tanabe S, Singh SA, Aikawa M (2015) New CETP inhibitor K-312 reduces PCSK9 expression: a potential effect on LDL cholesterol metabolism. Am J Physiol Endocrinol Metab 309:E177-E190. doi:10.1152/ajpendo.00528.2014

129. Moriarti PM, Parhofer KG, Babirak SP, Cornier M-A, Duell PB, Hohenstein B, Leebmann J, Ramlow W, Schettler V, Simha V, Steinhagen-Thiessen E, Thompson PD, Vogt A, von Stritzky B, Du Y, Manvelian G (2016) Alirocumab in patients with heterozygous familial hypercholesterolaemia undergoing lipoprotein apheresis: the Odyssey Escape trial. Eur Heart J 37:3588-3595. doi:10.1093/eurheartj/ehw388

130. Mortensen MB, Kjolby M, Gunnersen S, Larsen JV, Palmfeldt J, Falk E, Nykjaer A, Bentzon JF (2014) Targeting sortilin in immune cells reduces proinflammatory cytokines and atherosclerosis. J Clin Invest 124:5317-5322. doi:10.1172/ JCI76002

131. Mufti S, Wenzel S, Euler G, Piper HM, Schlüter K-D (2008) Angiotensin II-dependent loss of cardiac function: mechanisms and pharmacological targets attenuating this effect. J Cell Physiol 217:242-249. doi:10.1002/jcp.21501

132. Munck Petersen C, Nielsen MS, Jacobsen C, Tauris J, Jacobsen L, Gliemann J, Moestrup SK, Madsen P (1999) Propeptide cleavage conditions sortilin/neurotensin receptor-3 for ligand binding. EMBO J 18:595-604. doi:10.1093/emboj/18.3.595

133. Nassoury N, Blasiole DA, Tebon Oler A, Benjannet S, Hamelin J, Poupon V, McPherson PS, Attie AD, Prat A, Seidah NG (2007) The cellular trafficking of the secretory proprotein convertase PCSK9 and its dependence on the LDLR. Traffic 8:718-732. doi:10.1111/j.1600-0854.2007.00562.x

134. Ni YG, Condra JH, Orsatti L, Shen X, Di Marco S, Pandit S, Bottomley MJ, Ruggeri L, Cummings RT, Cubbon RM, Santoro JC, Ehrhardt A, Lewis D, Fisher TS, Ha S, Njimoluh L, Wood DD, Hammond HA, Wisniewski D, Volpari C, Noto A, Lo Surdo P, Hubbard B, Carfí A, Sitlani A (2010) A proprotein convertase subtilisin-like/kexin type 9 (PCSK9) C-terminal domain antibody antigen-binding fragment inhibits PCSK9 internalization and restores low density lipoprotein uptake. J Biol Chem 285:12882-12891. doi:10.1074/jbc.M110.113035

135. Nicholls S, Puri R, Anderson T, Ballantyne CM, Cho L, Kastelein JJP, Koenig W, Somaratne R, Kassahun H, Yang J, Wasserman SM, Scott R, Ungi I, Podolec J, Ophuis AO, Cornel JH, Borgman M, Brenann DM, Nissen SE (2016) Effect of evolocumab on progression of coronary disease in statin-treated patients: the GLAGOV randomized clinical trial. JAMA. doi:10. 1001/jama.2016.16951

136. Niesen M, Bedi M, Lopez D (2008) Diabetes alters LDL receptor and PCSK9 expression in rat liver. Arch Biochem Biophys 470:111-115. doi:10.1016/j.abb.2007.11.009

137. Nissen SE, Stroes E, Dent-Acosta RE, Rosenson RS, Lehman SJ, the GAUSS-3 Investigators (2016) Efficacy and tolerability of evolocumab vs. ezetimibe in patients with muscle-related statin intolerance: the GAUSS-3 randomized clinical trial. JAMA 315:1580-1590. doi:10.1001/jama.2016.3608

138. Osono Y, Woollett LA, Herz J, Dietschy JM (1995) Role of low density lipoprotein receptor in the flux of cholesterol through the plasma and across the tissue of the mouse. J Clin Invest 95:1124-1132. doi:10.1172/JCI117760
139. Padmasekar M, Nandigama R, Wartenberg M, Schlüter K-D, Sauer H (2011) The acute phase protein $\alpha 2$-macroglobulin induces rat ventricular cardiomyocytes hypertrophy via ERK1,2 and PI3-kinase/Akt pathways. Cardiovasc Res 75:118-128. doi:10.1016/j.cardiores.2007.03.003

140. Palmer-Smith H, Basak A (2010) Regulatory effects of peptides from the pro and catalytic domains of proprotein convertase subtilisin/kexin 9 (PCSK9) on low-density lipoprotein receptor (LDL-R). Curr Med Chem 17:2168-2182. doi:10.2174/ 092986710791299948

141. Park SW, Moon YA, Horton JD (2014) Post-transcriptional regulation of low density lipoprotein receptor protein by proprotein convertase subtilisin/kexin type 9a in mouse liver. J Biol Chem 279:50630-50638. doi:10.1074/jbc.M410077200

142. Perman JC, Boström P, Lindbom M, Lidberg U, Stahlman M, Hägg D, Lindskog H, Täng MS, Omerovic E, Hulten LM, Jeppsson A, Petursson P, Herlitz J, Olivecrona G, Strickland DK, Ekroos K, Olofsson SO, Boren J (2011) The VLDL receptor promotes lipotoxicity and increases mortality in mice following an acute myocardial infarction. J Clin Invest 121:2625-2640. doi:10.1172/JCI43068

143. Petersen DN, Hawkins J, Ruangsiriluk W, Stevens KA, Maguire BA, O'Connell TN, Rocke BN, Boehm M, Ruggeri RB, Rolph T, Hepworth D, Loria PM, Carpino PA (2016) A small-molecule anti-secretagogue of PCSK9 targets the 80S ribosome to inhibit PCSK9 protein translocation. Cell Chem Biol. doi:10.1016/j. chembiol.2016.08.016

144. Pirillo A, Norata GD, Catapano AL (2013) LOX-1, oxLDL, and atherosclerosis. Mediators Inflamm 2013:152786. doi:10.1155/ 2013/152786

145. Poirier S, Mamarbachi M, Chen WT, Lee AS, Mayer G (2015) GRP94 regulates circulating cholesterol levels through blockade of PCSK9-induced LDLR degradation. Cell Rep 13:2064-2071. doi:10.1016/j.celrep.2015

146. Prudencio M, Jansen-West KR, Lee WC, Gendron TF, Zhang YJ, Xu YF, Gass J, Stuani C, Stetler C, Rademakers R, Dickson DW, Buratti E, Petrucelli L (2012) Misregulation of human sortilin splicing leads to the generation of a nonfunctional progranulin receptor. Proc Natl Acad Sci USA 109:21510-21515. doi:10.1073/pnas.1211577110

147. Raal FJ, Hovingh GK, Blom D, Santos RD, Harada-Shiba M, Bruckert E, Couture P, Soran H, Watts GF, Kurtz C, Honarpour N, Tang L, Kasichavanula S, Wasserman SM, Stein EA (2017) Long-term effect with evolocumab added to conventional drug therapy, with or without apheresis, in patients with homozygous familian hyercholesterolaemia: an interim subset analysis of the open-label TAUSSIG study. Lancet Diabetes Endocrionol. doi:10.1016/S2213-8587(17)30044-X

148. Rashid S, Curtis DE, Garuti R, Anderson NN, Bashmakov Y, Ho YK, Hammer RE, Moon YA, Horton JD (2005) Decreased plasma cholesterol and hypersensitivity to statins in mice lacking PCSK9. Proc Natl Acad Sci USA 102:5374-5379. doi:10. 1073/pnas.0501652102

149. Ray KK, Ginsberg HN, Davidson MH, Pordy R, Bessac L, Minini P, Eckel RH, Cannon CP (2016) Reductions in atherogenic lipids and major cardiovascular events: a pooled analysis of 10 ODYSSEY trials comparing alirocumab with control. Circ Res 134:1931-1943. doi:10.1161/CIRCULATIONAHA.116. 024604

150. Reboullou A, Robert V, Vedie B, Doublet A, Grynberg A, Paul J-L, Fournire N (2012) Involvement of cholesterol efflux pathway in the control of cardiomyocytes cholesterol homeostasis. J Mol Cell Cardiol 53:196-205. doi:10.1016/j.yjmcc.2012.05. 015

151. Ridker PM, Revkin J, Amarenco P, Brunell R, Curto M, Civeira F, Flather M, Glynn RJ, Gregoire J, Jukema JW, Karpov Y, 
Kastelein JJ, Koenig W, Lorenzatti A, Manga P, Masiukiewicz U, Miller M, Mosterd A, Murin J, Nicolau JC, Nissen S, Ponikowski P, Santos RD, Schwartz PF, Soran H, White H, Wrigt RS, Vrablik M, Yunis C, Shear CL, Tardif JC, SPIRE Cardiovascular Outcome Investigators (2017) Cardiovascular efficacy and safety of bococizumab in high-risk patients. N Engl J Med. doi:10.1056/NEJMoa1701488

152. Ridker PM, Tardif JC, Amarenco P, Duggan W, Glynn RJ, Jukema JW, Kastelein JJ, Kim AM, Koenig W, Nissen S, Revkin J, Rose LM, Santos RD, Schwartz PF, Shear CL, Yunis C, SPIRE Investigators (2017) Lipid-reduction variability and antidrug-antibody formation with bococizumab. N Engl J Med. doi:10.1056/NEJMoa1614062

153. Rietzschel ER, Langlois M, de Buyzere ML, Segers P, de Bacquer D, Bekaert S, Cooman L, van Oostveldt P, Verdonck P, de Backer GG, Giullebert TC (2008) Oxidized low-density cholesterol is associated with decreases in cardiac function independent of vascular function. Hypertension 52:535-541. doi:10.1161/HYPERTENSIONAHA.108.114439

154. Robinson JG, Farnier M, Bergeron J, Luc G, Averna M, Stroes ES, Langslet G, Raal FJ, El Shahawy M, Koren MJ, Lepor NE, Lorenzato C, Pordy R, Chaudhari U, Kastelein JJ, ODYSSEYLONGTERM Investigators (2015) Efficacy and safety of alicorumab in reducing lipids and cardiovascular events. N Eng J Med 372:1489-1499. doi:10.1056/NEJMoa1501031

155. Robinson JG, Rosenson RS, Farnier M, Chaudhari U, Sasiela WJ, Merlet M, Miller K, Kastelein JJ (2017) Safety of very low low-density lipoprotein cholesterol levels with alirocumab: pooled data from randomized trials. J Am Coll Cardiol 69:471-482. doi:10.1016/j.jacc.2016.11.037

156. Rocha CS, Wiklander OP, Larsson L, Moreno PM, Parini P, Lundin LE, Smith CI (2015) RNA therapeutics inactivate PCSK9 by inducing a unique intracellular retention form. J Mol Cell Cardiol 82:186-193. doi:10.1016/j.yjmcc.2015.03.009

157. Rong S, Cortes VA, Rashid S, Anderson NN, McDonald JG, Liang G, Moon YA, Hammer RE, Horton JD (2017) Expression of SREBP-1c requires SREBP-2-mediated generation of a sterol ligand for LXR in livers of mice. eLife 6:e25015. doi:10.7554/ eLife25015

158. Roura S, Cal R, Galvez-Monton C, Revuelta-Lopez E, Nasarre L, Badimon L, Bayes-Genis A, Llorente-Cortes V (2014) Inverse relationship between raft LRP1 localization and non-raft ERK1,2/MMP9 activation in idiopathic dilated cardiomyopathy: potential impact in ventricular remodeling. Int $\mathrm{J}$ Cardiol 176:805-814. doi:10.1016/j.ijcard.2014.07.270

159. Ruscica M, Ricci C, Macchi C, Magni P, Cristofani R, Liu J, Corsini A, Ferri N (2016) Suppressor of cytokine signaling-3 (SOCS-3) induces proprotein convertase subtilisin kexin type 9 (PCSK9) expression in hepatic HepG2 cell line. J Biol Chem 291:3508-3519. doi:10.1074/jbc.M115.664706

160. Saavedra YG, Zhang J, Seidah NG (2013) PCSK9 prosegment chimera as novel inhibitors of LDLR degradation. PLoS One 8:e72113. doi:10.1371/journal.pone.0072113

161. Sabatine MS, Giugliano RP, Keech AC, Honarpour N, Wiviott SD, Murphy SA, Kuder JF, Wang H, Liu T, Wasserman SM, Sever PS, Pedersen TR, FOURIER Steering Committee and Investigators (2017) Evolocumab and clinical outcomes in patients with cardiovascular disease. N Engl J Med. doi:10. 1056/NEJMoa1615664

162. Sabatine MC, Giugliano RP, Wiviott SD, Raal FJ, Blom DJ, Robinson J, Ballantyne CM, Somaratne R, Legg J, Wasserman SM, Scott R, Koren MJ, Stein EA, for the Open-Label Study of Long-Term Evaluation against LDL Cholesterol (OSLER) Investigators (2015) Efficacy and safety of evolocumab in reducing lipids and cardiovascular events. $\mathrm{N}$ Engl $\mathrm{J}$ Med 372:1500-1509. doi:10.1056/NEJMoa1500858
163. Sahebkar A (2014) Circulating levels of proprotein convertase subtilisin kexin type 9 are elevated by fibrate therapy: a systematic review and meta-analysis of clinical trials. Cardiol Rev 22:306-312. doi:10.1097/CRD.0000000000000025

164. Sahebkar A, Simental-Mendia LE, Guerrero-Romero F, Golledge J, Watts GF (2015) Effect of statin therapy on plasma proprotein convertase subtilisin kexin 9 (PCSK9) concentrations: a systematic review and meta-analysis of clinical trials. Diabetes Obes Metab 17:1042-1055. doi:10.1111/dom.12536

165. Schiele F, Park J, Redemann N, Luippold G, Nar H (2014) An antibody against the C-terminal domain of PCSK9 lowers LDL cholesterol levels in vivo. J Mol Biol 426:843-852. doi:10.1016/ j.jmb.2013.11.011

166. Schlüter K-D, Wolf A, Weber M, Schreckenberg R, Schulz R (2017) Oxidized low-density lipoprotein (oxLDL) affects load free cell shortening of cardiomyocytes in a proprotein convertase subtilisin/kexin 9 (PCSK9)-dependent way. Basic Res Cardiol (submitted)

167. Schmidt AF, Swerdlow DI, Holmes MV, Patel RS, FairhurstHunter Z, Lyall DM, Hartwig FP, Horta BL, Hyppönen E, Power C, Moldovan M, van Iperen E, Hovingh GK, Demuth I, Norman K, Steinhagen-Thiessen E, Demuth J, Bertram L, Liu T, Coassin S, Willeit J, Kiechl S, Willeit K, Mason D, Wright J, Morris R, Wanamethee G, Whincup P, Ben-Shlomo Y, McLachlan S, Price JF, Kivimaki M, Welch C, Sanchez-Galvez A, Marques-Vidal P, Nicolaides A, Panayiotou AG, Onland-Moret NC, van der Schouw YT, Matullo G, Fiorito G, Guarrera S, Sacerdote C, Wareham NJ, Langenberg C, Scott R, Luan J, Bobak M, Malyutina S, Pająk A, Kubinova R, Tamosiunas A, Pikhart H, Husemoen LL, Grarup N, Pedersen O, Hansen T, Linneberg A, Simonsen KS, Cooper J, Humphries SE, Brilliant $M$, Kitchner $T$, Hakonarson $H$, Carrell DS, McCarty CA, Kirchner HL, Larson EB, Crosslin DR, de Andrade M, Roden DM, Denny JC, Carty C, Hancock S, Attia J, Holliday E, O’Donnell M, Yusuf S, Chong M, Pare G, van der Harst P, Said MA, Eppinga RN, Verweij N, Snieder H; LifeLines Cohort study group, Christen T, Mook-Kanamori DO, Gustafsson S, Lind L, Ingelsson E, Pazoki R, Franco O, Hofman A, Uitterlinden A, Dehghan A, Teumer A, Baumeister S, Dörr M, Lerch MM, Völker U, Völzke H, Ward J, Pell JP, Smith DJ, Meade T, Maitland-van der Zee AH, Baranova EV, Young R, Ford I, Campbell A, Padmanabhan S, Bots ML, Grobbee DE, Froguel P, Thuillier D, Balkau B, Bonnefond A, Cariou B, Smart M, Bao Y, Kumari M, Mahajan A, Ridker PM, Chasman DI, Reiner AP, Lange LA, Ritchie MD, Asselbergs FW, Casas JP, Keating BJ, Preiss D, Hingorani AD; UCLEB consortium, Sattar N (2017) PCSK9 genetic variants and risk of type 2 diabetes: a mendelian randomisation study. Lancet Diabetes Endocrinol 5:97-105. doi:10.1016/S22138587(16)30396-5

168. Schreckenberg R, Dyukova E, Sitdikova G, Abdallah Y, Schlüter K-D (2014) Mechanisms by which calcium receptor stimulation modifies electromechanical coupling in isolated ventricular cardiomyocytes. Pflugers Arch Eur J Physiol 467:379-388. doi:10.1007/s00424-014-1498-y

169. Schreckenberg R, Taimor G, Piper HM, Schlüter K-D (2004) Inhibition of $\mathrm{Ca}^{2+}$-dependent PKC isoforms unmasks ERK-dependent hypertrophic growth evoked by phenylephrine in adult ventricular cardiomyocytes. Cardiovasc Res 63:553-560. doi:10.1016/j.cardiores.2004.04.032

170. Schulz R, Schlüter K-D (2017) PCSK9 targets important for lipid metabolism. Clin Res Cardiol Suppl. doi:10.1007/s11789017-0085-0

171. Schulz R, Schlüter K-D, Laufs U (2015) Molecular and cellular function of the proprotein convertase subtilisin/kexin type 9 . Basic Res Cardiol 110:4. doi:10.1007/s00395-015-0463-Z 
172. Sehgal A, Vaishnaw A, Fitzgerald K (2013) Liver as a target for oligonucleotide therapeutics. Hepatology 59:1354-1359. doi:10. 1016/j.jhep.2013.05.045

173. Seidah NG, Awan Z, Chretien M, Mbikay M (2014) PCSK9: a key modulator of cardiovascular health. Circ Res 114:1022-1036. doi:10.1161/CIRCRESAHA.114.301621

174. Seidah NG, Benjannet S, Wickham L, Marcinkiewicz J, Jasmin SB, Stifani S, Basak A, Prat A, Chretien M (2003) The secretory proprotein convertase neural apoptosis-regulated convertase 1 (NARC-1): liver regeneration and neuronal differentiation. Proc Natl Acad Sci USA 100:928-933. doi:10.1073/pnas. 0335507100

175. Seidah NG, Poirier S, Denis M, Parker R, Miao B, Mapelli C, Prat A, Wassef H, Davignon J, Hajjar KA, Mayer G (2012) Annexin A2 is a natural extrahepatic inhibitor of the PCSK9induced LDL receptor degradation. PLoS One 7:e41865. doi:10. 1371/journal.pone.0041865

176. Seidah NG, Prat A (2012) The biology and therapeutic targeting of the proprotein convertases. Nat Rev Drug Discov 11:367-383. doi: $10.1038 / \mathrm{nrd} 3699$

177. Shan L, Pang L, Zhang R, Murgolo NJ, Lan H, Hedrick JA (2008) PCK9 binds to multiple receptors and can be functionally inhibited by an EGF-A peptide. Biochem Biophys Res Commun 375:69-73. doi:10.1016/j.bbrc.1008.07.106

178. Shen T, James DE, Krueger KA (2016) Population pharmacokinetics (PK) and pharmacodynamics (PD) analysis of Ly3015014, a monoclonal antibodyt o protein converatse subtilisin/kexin type 9 (PCSK9) in healthy subjects and hypercholesterolemic patients. Pharm Res. doi:10.1007/s11095-0162054-6

179. Shende VR, Wu M, Singh AB, Dong B, Can CF, Liu J (2015) Reduction of PCSK9 and LDL-C levels by liver-specific knockdown of HNF1alpha in normolipemic mice. J Lipid Res 56:801-809. doi:10.1194/jlr.M052969

180. Shioji K, Mannami T, Kokubo Y, Inamoto N, Takagi ST, Goto Y, Nonogi H, Iwai N (2004) Genetic variants in PCSK9 affect the cholesterol levels in Chinese. J Hum Genet 49:109-114. doi:10.1007/s10038-003-0114-3

181. Silverman MG, Ference BA, Kyungah I, Wiviott SD, Giugliano RP, Grundy SM, Braunwald E, Sabatine MS (2016) Association between lowering LDL-C and cardiovascular risk reduction among different therapeutic interventions. JAMA 316:1289-1297. doi:10.1001/jama.2016.13985

182. Spallarossa P, Fabbi P, Manca V, Garibaldi S, Ghigliotti G, Barisione C, Altieri P, Patrone F, Brunelli C, Barsotti A (2005) Doxorubicin-induced expression of LOX-1 in H9c2 cardiac muscle cells and its role in apoptosis. Biochem Biophys Res Commun 335:188-196. doi:10.1016/j.bbrc.5005.07.064

183. Stein EA, Honarpour N, Wasserman SM, Xu F, Scott R, Raal V (2013) Effect of the proprotein convertase subtilisin/kexin 9 monoclonal antibody, AMG 145, in homozygous familial hypercholesterolemia. Circulation 128:2113-2120. doi:10.1161/ CIRCULATIONAHA.113.004678

184. Stroes ES, Colquhoun D, Sullivan D, Civeira F, Rosenson RS, Watts GF, Bruckert E, Cho L, Dent R, Knusel B, Xue A, Scott R, Wasserman SM, Rocco M (2014) Anti-PCSK-9 Antibody effectively lowers cholesterol in patients with statin intolerance. J Am Coll Cardiol 63:2541-2548. doi:10.1016/j.jacc.2014.03. 019

185. Stroes ES, Thompson PD, Corsini A, Vladutiu GD, Raal FJ, Ray KK, Roden M, Stein E, Tokgözoğlu L, Nordestgaard BG, Bruckert E, De Backer G, Krauss RM, Laufs U, Santos RD, Hegele RA, Hovingh GK, Leiter LA, Mach F, März W, Newman CB, Wiklund O, Jacobson TA, Catapano AL, Chapman MJ, Ginsberg HN (2015) Statin-associated muscle symtoms: impact on statin therapy-European Atherosclerosis Society Consensus
Panel Statement on Assessment, Aetiology and Management. Eur Heart J 36:1012-1022. doi:10.1093/eurheartj/ehv043

186. Strom TB, Holla OL, Tveten K, Cameron J, Berge KE, Leren TP (2010) Disrupted recycling of the low density lipoprotein receptor by PCSK9 is not mediated by residues of the cytoplasmic domain. Mol Genet Metab 101:76-80. doi:10.1016/j. ymgme.2010.05.003

187. Stucchi M, Grazioso G, Lammi C, Manara S, Zanoni C, Arnoldi A, Lesma G, Silvani A (2016) Disrupting the PCSK9/LDLR protein-protein interaction by an imidazole-based minimalist peptidomimetic. Org Biomol Chem 14:9736-9740. doi:10.1039/ C6OB01642A

188. Tang Z, Jiang L, Peng J, Ren Z, Wei D, Wu C, Pan L, Jiang Z, Liu L (2012) PCSK9 siRNA suppresses the inflammatory response induced by oxLDL through inhibition of NF- $\kappa \mathrm{B}$ activation in THP-1-derived macrophages. Int $\mathrm{J}$ Mol Med 30:931-938. doi:10.3892/ijmm.2012.1072

189. Tao R, Xiong X, DePinho RA, Deng CX, Dong XC (2013) Hepatic SREBP-2 and cholesterol biosynthesis are regulated by FoxO3 and Sirt6. J Lipid Res 54:2745-2753. doi:10.1194/jlr. M039339

190. Tao R, Xiong X, DePinho RA, Deng CX, Dong XC (2013) FoxO3 transcription factor and Sirt6 deacetylase regulate low density lipoprotein (LDL)-cholesterol homeostasis via control of the proprotein convertase subtilisin/kexin 9 (PCSK9) gene expression. J Biol Chem 288:29252-29259. doi:10.1074/jbc. M113.481473

191. Tavori H, Fan D, Blakemore JL, Yancey PG, Ding L, Linton MF, Fazio S (2013) Serum protease converatse subtilisin/kexin type 9 and cell surface low-density lipoprotein receptor: evidence for a reciprocal regulation. Circulation 127:2403-2413. doi:10.1161/CIRCULATIONAHA.113.0011592

192. Timms KM, Wagner S, Samuels ME, Forbey K, Goldfine H, Jammulapati S, Skolnick MH, Hopkins PN, Hunt SC, Shattuck DM (2004) A mutation in PCSK9 causing autosomal-dominant hypercholesterolemia in a Utah pedigree. Hum Genet 114:349-353. doi:10.1007/s00439-003-1071-9

193. Toth PP, Descamps O, Genest J, Sattar N, Preiss D, Dent RE, Djedjos CS, Wu Y, Geller M, Uhart M, Somaratne R, Wasserman SM, Investigators PROFICIO (2017) Pooled safety analysis of evolocumab in over 6000 patients from double-blind and open-label extension studies. Circulation. doi:10.1116/CIRCU LATIONAHA.116.025233

194. Toth PP, Hamon SC, Jones SR, Martin SS, Joshi PH, Kulkarni KR, Banerjee P, Hanotin C, Roth EM, McKenney JM (2016) Effect of alirocumab on specific lipoprotein non-high-density lipoprotein cholesterol and subfractions as measured by the vertical auto profile method: analysis of 3 randomized trials versus placebo. Lipids Health Dis 15:28. doi:10.1186/s12944016-0197-4

195. Troutt JS, Alborn WE, Cao G, Konrad RJ (2010) Fenofibrate treatment increases human serum proprotein converatse subtilisin kexin type 9 levels. J Lipid Res 51:345-351. doi:10.1194/jlr. M000620

196. Tsutsui T, Tsuatamoto T, Wada A, Maeda K, Mabuchi N, Hayashi M, Ohnishi M, Kinoshita M (2002) Plasma oxidized low-density lipoprotein as a prognostic predictor in patients with chronic congestive heart failure. J Am Coll Cardiol 39:957-962. doi:10.1016/S0735-1097(02)01721-7

197. Vallejo-Vaz AJ, Sashasi SRK, Cole D, Hovingh GK, Kastelein JJP, Mata P, Raal FJ, Santos RD, Soran H, Watts GF, Abifadel M, Aguilar-Salinas CA, Akram A, Alnouri F, Alonso R, AlRasadi K, Banach M, Bogsrud MP, Bourbon M, Bruckert E, Car J, Corral P, Descamps O, Dieplinger H, Durst R, Freiberger T, Gaspar IM, Genest J, Harada-Shiba M, Jiang L, Kayikcioglu M, Lam CSP, Latkovskis G, Laufs U, Liberopoulos E, Nilsson L, 
Nordestgaard BG, O’Donoghue JM, Sahebkar A, Schunkert H, Shehab A, Stoll M, Su TC, Susekov A, Widen E, Catapano AL, Ray KK (2015) Familial hypercholesterolaemia: a global call to arms. Atherosclerosis 243:257-259. doi:10.1016/j.athero sclerosis.2015.09.021

198. Van Poelgeest EP, Hodges MR, Moerland M, Tesiier Y, Levin AA, Persson R, Lindholm MW, Dumong Erichsen K, Orum H, Cohen AF, Burggraaf J (2015) Antisense-mediated reduction of proprotein convertase subtilisin/kexin type 9 (PCSK9): a first-inhuman randomized, placebo-controlled trial. $\mathrm{Br} \mathrm{J}$ Clin Pharmacol 80:1350-1361. doi:10.1111/bcp.12738

199. Van Poelgeest EP, Swart RM, Betjes MG, Moerland M, Weening JJ, Tessier Y, Hodges MR, Levin AA, Burggraf J (2013) Acute kidney injury during therapy with an antisense oligonucleotide directed against PCSK9. Am J Kidney Dis 62:796-800. doi:10.1053/j.ajkd.2013.02.359

200. Walley KR, Thain KR, Russell JA, Reilly MP, Meyer NJ, Ferguson JF, Christie JD, Nakada TA, Fjell CD, Thair SA, Cirstea MS, Boyd JH (2014) PCSK9 is a critical regulator of the innate immune response and septic shock outcome. Sci Transl Med 6:25843. doi:10.1126/scitranslmed.3008782

201. Wang N, Tall AR (2017) A new approach to PCSK9 therapies. Circ Res. doi:10.1161/CIRCRESAHA.117.310610

202. Wang X, Berry E, Hernandez-Anzaldo S, Sun D, Adijiang A, Li L, Zhang D, Fernandez-Patron C (2015) MMP-2 inhibits PCSK9-induced degradation of the LDL receptor in Hepa1-c1c7 cells. FEBS Lett 589:490-496. doi:10.1016/j.febslet.2015.01. 007

203. Wang X, Raghavan A, Chen T, Qiao L, Zhang Y, Ding Q, Musunuru K (2016) CRISPR-Cas9 targeting of PCSK9 in human hepatocytes in vivo. Arterioscler Thromb Vasc Biol 36:783-786. doi:10.1161/ATVBAHA.116.307227

204. Wang Y, Huang Y, Hobbs HH, Cohen JC (2012) Molecular characterization of proprotein convertase subtilisin/kexin type 9-mediated degradation of the LDLR. J Lipid Res 53:1932-1943. doi:10.1194/jlr.M028563

205. Wang Y, Ye J, Li J, Chen C, Huang J, Liu P, Huang H (2016) Polydatin ameliorates lipid and glucose metabolism in type 2 diabetes mellitus by downregulating proprotein convertase subtilisin/kexase type 9 (PCSK9). Cardiovasc Diabetol. doi:10. 1186/s12933-015-0325-x

206. Weider E, Susan-Resiga D, Essalmani R, Hamelin J, Asselin MC, Nimesh S, Ashraf Y, Wycoff KL, Zhang J, Prat A, Seidah
NG (2016) Proprotein convertase subtilisin/kexin type 9 (PCSK9) single domain antibodies are potent inhibitors of low density lipoprotein receptor degradation. J Biol Chem 291:16659-16671. doi:10.1074/jbc.M116.717736

207. Wierod L, Cameron J, Strom TB, Leren TP (2016) Studies on the autoinhibitory segment comprising residues $31-60$ of the prodaomain of PCSK9: possible implication for the mechanism underlying gain-of-function mutation. Mol Genet Metab Rep 17:86-93. doi:10.1016/j.ymgmr.2016.11.003

208. Wu CY, Tang ZH, Jiang L, Li XF, Jiang ZS, Liu LS (2012) PCSK9 siRNA inhibits HUVEC apoptosis induced by ox-LDL via Bcl/Bax-caspase9-caspase3 pathway. Mol Cell Biochem 359:347-358. doi:10.1007/s11010-011-1028-6

209. Zhang Y, Eigenbrot C, Zhou L, Shia S, Li W, Quan C, Tom J, Moran P, Di LP, Skelton NJ, Kong-Beltram M, Peterson A, Kirchhofer D (2014) Identification of a small peptide that inhibits PCSK9 protein binding to the low density lipoprotein receptor. J Biol Chem 289:942-955. doi:10.1074/jbc.M113. 514067

210. Zhang DW, Garuti R, Tang WJ, Cohen JC, Hobbs HH (2008) Structural requirements for PCSK9-mediated degradation of the low-density lipoprotein receptor. Proc Natl Acad Sci USA 105:13045-13050. doi:10.1073/pnas.0806312105

211. Zhang DW, Lagace TA, Garuti R, Zhao Z, McDonald M, Horton JD, Cohen JC, Hobbs HH (2007) Binding of proprotein convertase subtyilisin/kexin type 9 to epidermal growth factorlike repeat A of low density lipoprotein receptor decreases receptor recycling and increases degradation. J Biol Chem 282:18602-18612. doi:10.1074/jbc.M702027200

212. Zhao X, Zhang HW, Li S, Zhang Y, Xu RX, Zhu CG, Wu NQ, Guo YL, Qing P, Li XL, Liu G, Dong Q, Sun J, Li J (2017) ANNALS EXPRESS: association between plasma proprotein convertase subtilisin/kexin type 9 level and coronary artery calcification. Ann Clin Biochem. doi:10.1177/ 0004563217695351

213. Zorn-Pauly K, Schaffer P, Pelzmann B, Bernhart E, Wei G, Lang P, Ledinski G, Greilberger J, Koidl B, Jürgens G (2005) Oxidized LDL induces ventricular myocytes damage and abnormal electrical activity-role of lipid hydroperoxides. Cardiovasc Res 66:74-83. doi:10.1016/j.cardiores.2004.12.009 